\title{
250-year records of mercury and trace element deposition in two lakes from Cajas National Park, SW Ecuadorian Andes
}

\author{
Tobias Schneider ${ }^{1,2,3}$ - Benjamin A. Musa Bandowe ${ }^{1,2,4} \cdot$ Moritz Bigalke $^{2} \cdot$ Adrien Mestrot $^{2} \cdot$ Henrietta Hampel $^{5,6}$. \\ Pablo V. Mosquera ${ }^{7,8} \cdot$ Lea Fränkl $^{1,2} \cdot$ Giulia Wienhues $^{1,2} \cdot$ Hendrik Vogel $^{1,9} \cdot$ Wojciech Tylmann $^{10} \cdot$ Martin Grosjean $^{1,2}$
}

Received: 25 May 2020 / Accepted: 26 October 2020 / Published online: 5 December 2020

(C) The Author(s) 2020

\begin{abstract}
Historical records of trace elements in lake sediments provide source-to-sink information about potentially toxic pollutants across space and time. We investigated two lakes located at different elevations in the Ecuadorian Andes to understand how trace element fluxes are related to (i) geology, (ii) erosion in the watersheds, and (iii) local point sources and atmospheric loads. In remote Lake Fondococha (4150 m a.s.1.), total Hg fluxes stay constant between ca. 1760 and 1950 and show an approximately 4.4-fold increase between pre-1950 and post-1950 values. The post-1950 increase in fluxes of other trace elements ( $\mathrm{V}, \mathrm{Cr}, \mathrm{Co}, \mathrm{Ni}, \mathrm{Cu}, \mathrm{Zn}, \mathrm{As}, \mathrm{Cd}$, and $\mathrm{Pb}$ ) is lower (2.1-3.0-fold) than for $\mathrm{Hg}$. Mostly lithogenic sources and enhanced soil erosion contribute to their post-1950 increase (lithogenic contribution: > 85\%, Hg: 58\%). Average post-1950 Hg fluxes are approximately 4.3 times higher in peri-urban Lake Llaviucu (3150 m a.s.l.) than in the remote Lake Fondococha. Post-1950 fluxes of the other trace elements showed larger differences between Lakes Fondococha and Llaviucu $(5.2<25-$ 29.5 -fold increase; $\mathrm{Ni}<\mathrm{Pb}-\mathrm{Cd}$ ). The comparison of the post-1950 average trace element fluxes that are derived from point and airborne sources revealed 5-687 $(\mathrm{Hg}-\mathrm{Pb})$ times higher values in Lake Llaviucu than in Lake Fondococha suggesting that Lake Llaviucu's proximity to the city of Cuenca strongly influences its deposition record (industrial emissions, traffic, caged fishery). Both lakes responded with temporary drops in trace element accumulations to park regulations in the 1970s and 1990s, but show again increasing trends in recent times, most likely caused by increase in vehicular traffic and openings of copper and gold mines around Cajas National Park.
\end{abstract}

Keywords Mercury $\cdot$ Trace elements $\cdot$ Heavy metals $\cdot$ Environmental reconstruction $\cdot$ Lake sediments $\cdot$ Paleolimnology Anthropocene $\cdot$ Andes

Responsible Editor: Severine Le Faucheur

Tobias Schneider

tobias.schneider@giub.unibe.ch; tobiasschnei@umass.edu

1 Oeschger Centre for Climate Change Research, University of Bern, Hochschulstrasse 4, 3012 Bern, Switzerland

2 Institute of Geography, University of Bern, Hallerstrasse 12, 3012 Bern, Switzerland

3 Department of Geosciences, University of Massachusetts Amherst, 611 North Pleasant Street, Amherst, MA 01003-9297, USA

4 Multiphase Chemistry Department, Max Planck Institute for Chemistry, Hahn-Meitner-Weg 1, 55128 Mainz, Germany

5 Facultad de Ciencias Químicas, Universidad de Cuenca, Cuenca, Ecuador
6 Laboratorio de Ecología Acuática, Departamento de Recursos Hídricos y Ciencias Ambientales, Universidad de Cuenca, Cuenca, Ecuador

7 Subgerencia de Gestión Ambiental, Empresa Pública Municipal de Telecomunicaciones, Agua potable, Alcantarillado y Saneamiento (ETAPA EP), Cuenca, Ecuador

8 Departament de Biologia Evolutiva, Ecologia i Ciències Ambientals, Universitat de Barcelona, Barcelona, Spain

9 Institute of Geological Sciences, University of Bern, Baltzerstrasse 1+3, 3012 Bern, Switzerland

10 Faculty of Oceanography and Geography, University of Gdansk, Bazynskiego 4, 80309 Gdansk, Poland 


\section{Introduction}

Trace elements (here $\mathrm{V}, \mathrm{Cr}, \mathrm{Co}, \mathrm{Ni}, \mathrm{Cu}, \mathrm{Zn}, \mathrm{As}, \mathrm{Cd}, \mathrm{Pb}$, and $\mathrm{Hg}$ ) in the environment are a global concern, due to their potential toxicity to living organisms (Tchounwou et al. 2012; Beal et al. 2014; Sundseth et al. 2017) and their effects on environmental processes (Chojnacka 2018). They follow different pathways in the atmosphere, the hydrosphere and on land, depending on their physicochemical characteristics (Rauch and Pacyna 2009; Beal et al. 2013; Driscoll et al. 2013). Most trace elements in the environment originate from natural sources (e.g., volcanic activity) and from anthropogenic emissions (Konieczka et al. 2018). Anthropogenically derived trace elements have specific spatially and temporally explicit trajectories of production rates from prehistoric to industrial times (e.g., mining and amalgamation, fossil fuel combustion, and industrial emissions; Streets et al. 2011; Cooke and Bindler 2015). The least volatile elements can be bound to large particles and are mostly deposited close to their point sources whereas the more volatile ones (gaseous; such as $\mathrm{Hg}$ ) may be transported over long distances in the atmosphere (Schroeder and Munthe 1998; Phillips et al. 2011). This leads to pronounced spatial and temporal variability of depositional rates across the world (Selin et al. 2008; Strode et al. 2009; Streets et al. 2011; Engstrom et al. 2014; Cooke and Bindler 2015).

Lake sediments are very valuable environmental archives for documenting past deposition of trace elements and $\mathrm{Hg}$ from natural and anthropogenic activities (Smol 2008; Boyle et al. 2015). Most of the high-resolution $\mathrm{Hg}$ records span the ${ }^{210} \mathrm{~Pb}$ dating range of the past 150 years, and the study sites are predominantly located in the midand high-latitude areas of the northern hemisphere, with very few records in the southern hemisphere mid-latitudes and the inner tropics (Perry et al. 2005; Biester et al. 2007; Cooke et al. 2009; Beal et al. 2013; Beal et al. 2014; Engstrom et al. 2014; Álvarez et al. 2018; Engels et al. 2018; Guédron et al. 2018; Guédron et al. 2019). A majority of the sediment records from the northern hemisphere reveal an overall 2-5-fold increase of $\mathrm{Hg}$ deposition rates from pre-industrial to modern (1950-2000+) times (Fitzgerald et al. 1998; Landers et al. 1998; Perry et al. 2005; Biester et al. 2007; Mast et al. 2010; Pirrone et al. 2010; Beal et al. 2013; Engstrom et al. 2014) and provide critically important information about "natural" background and anthropogenic depositional rates for times long before direct measurements became available. Moreover, reconstructions provide data to constrain global Hg models (Strode et al. 2009). All this, in combination, makes it important to understand depositional rates (fluxes) across the world and through time, particularly in remote high-mountain and arctic environments (Schroeder and Munthe 1998; Phillips et al. 2011).
Refining the network of historical trace element and $\mathrm{Hg}$ flux records across the globe remains a coveted goal. Specific goals include among other (i) assessing preanthropogenic (natural) background levels of potentially toxic trace elements, (ii) assessing the differences between the historical legacy (here restricted to the period 1760 1950) and the modern era (post-1950) in terms of the levels and composition profiles of trace elements, and (iii) the apportionment of sources, i.e., differentiation of local sources (e.g., from the catchment, and point sources) from sources related to long-range atmospheric transport (Perry et al. 2005).

Here, we present the depositional history of $\mathrm{Hg}$ and other trace elements $(\mathrm{V}, \mathrm{Cr}, \mathrm{Co}, \mathrm{Ni}, \mathrm{Cu}, \mathrm{Zn}, \mathrm{As}, \mathrm{Cd}$, and $\mathrm{Pb}$ ) as recorded in lake sediments from Cajas National Park (CNP) in the high Andes of southwestern Ecuador. CNP forms part of the UNESCO Biosphere Reserve. It is recognized for its biodiversity and wetlands and is considered as one of the most pristine areas in the high Andean grasslands, the Páramo. The high Andean CNP provides approximately $60 \%$ of the citizens of the city of Cuenca with fresh water (Mosquera et al. 2017). However, the Ecuadorian Ministry of Mining granted exploratory mining concessions and, thus, large areas around the park have recently become active registered mining sites and large-scale gold mines are currently under construction (Roy et al. 2018).

In the present study, we compare two nearby lakes: Lake Llaviucu (3150 m a.s.1.), a peri-urban lake in the vicinity of the city of Cuenca and surrounded by montane forest, and remote Lake Fondococha (4130 m a.s.l), a highelevation lake in the Páramo grassland. In these same lakes, Bandowe et al. (2018) have established that fluxes of polycyclic aromatic compounds (PACs) are 4-5 times higher in the lower-elevation peri-urban Lake Llaviucu than in remote high-elevation Lake Fondococha. They concluded that the cloud condensation maximum (3500 $\mathrm{m}$ a.s.1.) in combination with denser vegetation seem to scavenge and remove organic pollutants at lower elevations very efficiently from the atmosphere. Furthermore, they found that remote Lake Fondococha (above the cloud-layer maximum) shows a PAC profile with much larger contributions of long-distance transported pollutants, whereas the sources for PACs in the lower periurban Lake Llaviucu are mostly locally derived (traffic, combustion, and industrial emissions from Cuenca; Bandowe et al. 2018). Yet, no study from this region has investigated whether similar mechanisms apply for the deposition of $\mathrm{Hg}$ and other trace elements.

Guided by the scientific challenges mentioned above, we addressed the following questions in the present study: (i) What is the temporal pattern of $\mathrm{Hg}$ and other trace elements deposition in two lakes (high-altitude and 
remote, and lower-altitude and located in peri-urban area) over the past approximately 250 years? Are the source patterns for $\mathrm{Hg}$ (mostly gaseous) different from other trace elements that are mostly bound to particulate aerosols (following the apportionment approach from Perry et al. 2005)? (ii) What is the role of anthropogenic emissions and increased erosion in the catchment (comparing post-1950 to pre-1950 conditions), and which part may be attributed to point sources (directly in the catchment, and in the lake), local sources from the city of Cuenca, or long-distance atmospheric transport?

\section{Material and methods}

\section{Regional setting}

Both studied lakes are located in the Cajas National Park (CNP; $2^{\circ} 50^{\prime} \mathrm{S}, 79^{\circ} 10^{\prime} \mathrm{W}$, Fig. 1) on the eastern slope of the western Andean Cordillera in the Azuay Province, southern Ecuador. Approximately $80 \%$ of the park area belongs to the Pleistocene Tarqui formation (tuff, rhyolite, and andesite; Paladines et al. 1980). CNP is also exposed to the ashfall trajectories of different still active volcanoes (Arcusa et al.

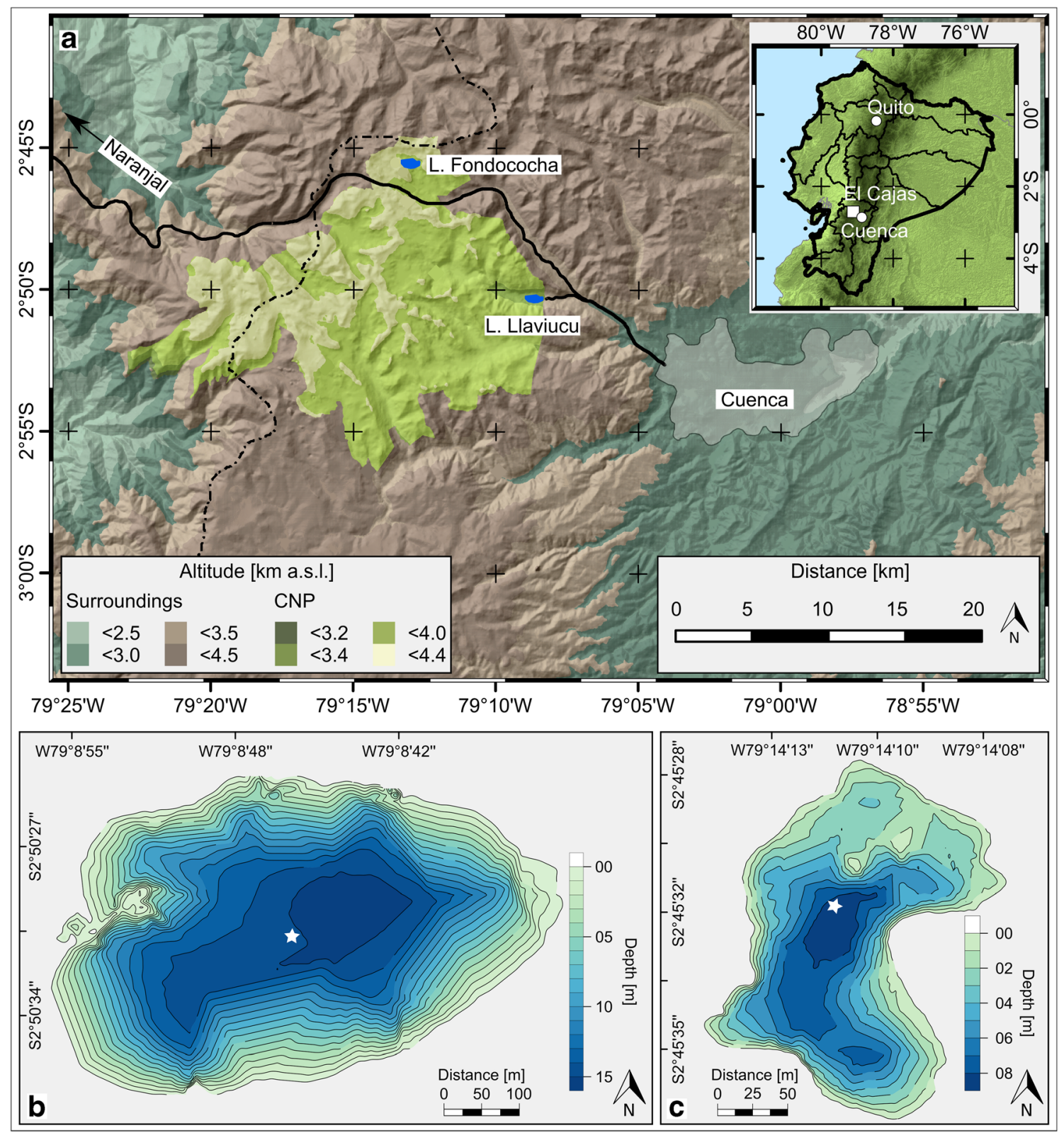

Fig. 1 Geographic location of Lakes Llaviucu and Fondococha in Cajas National Park. a Cajas National Park (green shaded area) in southern Ecuador with the continental divide (dashed line), the highway (black line), and the city of Cuenca. Bathymetric maps for Lake Llaviucu (b) and Lake Fondococha (c) with the coring sites (white asterisks). (Adapted from Bandowe et al. 2018) 
2020). The soils in the watersheds are therefore mostly of volcanic origin (non-allophanic Andosols and Histosols) and are characterized by a high organic matter content (Mosquera et al. 2017).

Lake Fondococha $\left(2^{\circ} 45^{\prime} 35^{\prime \prime} \mathrm{S}, 79^{\circ} 14^{\prime} 11^{\prime \prime} \mathrm{W}\right)$ is a small (3.4 ha) oligotrophic remote postglacial lake at high-elevation (4130 m a.s.l.) in the Páramo grasslands, substantially above the precipitation maximum which is at $3500 \mathrm{~m}$ a.s.1 (Schneider et al. 2018). The lake is $9.9 \mathrm{~m}$ deep and the catchment is relatively small $\left(0.6 \mathrm{~km}^{2}\right.$, catchment area/lake area ratio $=18$; Mosquera et al. 2017).

Lake Llaviucu $\left(2^{\circ} 50^{\prime} 36^{\prime \prime} \mathrm{S}, 79^{\circ} 8^{\prime} 46^{\prime \prime} \mathrm{W}\right)$, in contrast, is a mesotrophic exorheic lake, dammed by a terminal moraine (ca. 35,000 cal. years BP; Colinvaux et al. 1997) with a surface area of 18.9 ha and a maximum depth of $16.5 \mathrm{~m}$. The lake is located at relatively lower elevation (3140 $\mathrm{m}$ a.s.l.) in the montane rain forest belt below the precipitation maximum and the cloud condensation level (3500 $\mathrm{m}$ a.s.l). The distance to Lake Fondococha is approximately $13.5 \mathrm{~km}(\mathrm{NW})$ and Lake Llaviucu is close to the suburbs of Cuenca $(<10 \mathrm{~km})$. The Cuenca-Molleturo-Naranjal highway (Fig. 1) passes within $2 \mathrm{~km}$ of the lake and an intensive caged fishery was established in the lake between 1978 and 1998 (data provided by ETAPA EP). The catchment of Lake Llaviucu $\left(\sim 47.7 \mathrm{~km}^{2}\right)$ is substantially larger and ranges up to the Páramo belt (catchment area/lake area ratio $=252$; Mosquera et al. 2017).

The area of CNP, including the catchments of both lakes, has been subject to human activities since the late Holocene (since ca. 4000 cal. years BP; Hansen et al. 2003). Deforestation, grazing, and grassland burning was particularly intense in the second half of the twentieth century before the founding of the recreational area (1977) and the National Park (1996). Bandowe et al. (2018) concluded from ${ }^{210} \mathrm{~Pb}$ dated sediment cores of both lakes that sediment mass accumulation rates (MARs) were remarkably constant prior to 1960 but rapidly increased afterwards by a factor of 2 , reflecting mostly soil erosion from the catchment. High MARs (soil erosion) were observed until the late 1980s when they started to decrease slowly as human activities decreased with increasing environmental protection. Given the economic development of the city of Cuenca, we define here the "modern era" as post1950 (phase of Great Acceleration; Steffen et al. 2015). Arcusa et al. (2020) recently identified several distinguished volcanic ash layers (macro tephra layers) in the sediments of both studied lakes. However, no tephra layers were detected in the last approximately 250 years.

\section{Sediment sampling and chronostratigraphy}

In 2014, annually integrating sediment traps (July 2014-July 2015) were deployed at the depocenter and short sediment cores were retrieved from the depocenter of the two lakes (Fig. 1) using a gravity coring system (UWITEC, Austria).
The sediment-water interfaces of the retrieved sediment cores were preserved with wet floral foam to guarantee safe shipment. The cores were kept at dark and cool $\left(4^{\circ} \mathrm{C}\right)$ conditions until they were split lengthwise in the laboratory, sedimentologically described, and photographed (Schnurrenberger et al. 2003). Prior to physical subsampling, the half cores were scanned with an $\mu$ XRF-system (ITRAX; Croudace et al. 2006) equipped with a Mo-tube. The exposure time was set to $10 \mathrm{~s}$, the current to $35 \mathrm{~mA}$, and the voltage to $30 \mathrm{kV}$. One core half per core (FON14-1 and LLA14-1) was stratigraphically sampled at $0.5-\mathrm{cm}$ increments down to $12 \mathrm{~cm}$ in Lake Fondococha (lower sedimentation rate; Bandowe et al. 2018) and down to $35 \mathrm{~cm}$ in Lake Llaviucu (higher sedimentation rate; Bandowe et al. 2018) for $\mathrm{Hg}$ and trace element analyses. The concentrations of carbon, nitrogen, and sulfur $(\mathrm{C}, \mathrm{N}, \mathrm{S})$, and polycyclic aromatic compound (PACs) data in these same sediments were adopted from a previous study (Bandowe et al. 2018). Radionuclide samples $\left({ }^{210} \mathrm{~Pb}\right.$ and $\left.{ }^{226} \mathrm{Ra}\right)$ used for the chronologies were determined at the same intervals on the parallel core halves in a previous study (Bandowe et al. 2018), following the methods described in Tylmann et al. (2016). After testing varying age-depth model assumptions (von Gunten et al. 2009), we decided to use the constant rate of supply (CRS) age-depth models (Appleby and Oldfield 1978) with missing inventory corrections (Tylmann 2014) to calculate sediment ages and mass accumulation rates (MAR). Here, we adopt the sediment ages and MARs as published in Bandowe et al. (2018) and projected them further back in time (Lake Fondococha: ca. 1760; Lake Llaviucu: ca. 1780) based on linear extrapolation of the last four measured samples (Lake Fondococha: 1857-1890; Lake Llaviucu: 1891-1908).

All statistical analyses were conducted in R (R Core Team 2019) using the "vegan" (Oksanen et al. 2019), "factoextra" (Kassambara and Mundt 2017), and "corrplot" (Wei and Simko 2017) packages.

\section{Mercury and trace element analyses}

One hundred milligrams of lyophilized and homogenized sediment (per sediment core sample and sediment trap sample) were digested in Teflon vessels with $8 \mathrm{ml} \mathrm{HNO} 3(69 \%$, grade "supra pure") and $2 \mathrm{ml} \mathrm{H}_{2} \mathrm{O}_{2}$ (30\%, grade "supra pure") in a microwave oven (Ethos contFLOW1600, Milestone, Shelton CT, USA, detailed program in Tab. S1). The digests were split into two portions, one was stabilized with $\mathrm{HCl}$ and used for $\mathrm{Hg}$ analysis and the other one was analyzed for the other trace elements. Each microwave batch included eight sediment samples in separate vessels, one vessel containing certified reference material (CRM, 2709a San Joaquin Soil, National Institute of Standards and Technology; Mackey et al. 2010), and one blank vessel (only with $8 \mathrm{ml} \mathrm{HNO}_{3}$ and $2 \mathrm{ml} \mathrm{H}_{2} \mathrm{O}_{2}$ ). 
The trace element and $\mathrm{Hg}$ concentrations in digests were determined using an inductively coupled plasma mass spectrometer (ICP-MS; 7700x, Agilent Technologies, Santa Clara, USA). ICP-MS is an analytical technique commonly used to analyze $\mathrm{Hg}$ and other trace elements (D'Ilio et al. 2010; Djedjibegovic et al. 2012). Mercury and the other trace elements were measured separately with optimized operating parameters (Tab. S2). Rhodium and indium were used as instrumental internal standards. To avoid carry-over effects ("memory-effects"; Li et al. 2006), the Hg samples and standards were diluted to concentrations lower than $2 \mu \mathrm{g} \mathrm{l}^{-1}$ and, furthermore, after running each sample the system was rinsed with an (i) alkaline solution (EDTA Triton X), an (ii) acid solution $\left(5 \% \mathrm{HNO}_{3}, 5 \% \mathrm{HCl}\right)$, and also (iii) the sample's matrix solution $\left(1 \% \mathrm{HNO}_{3}, 0.5 \% \mathrm{HCl}\right)$. The maximum blank values varied between $1.126 \mu \mathrm{g} \mathrm{L}^{-1}$ for $\mathrm{Zn}$ and $0.004 \mu \mathrm{g} \mathrm{L}^{-1}$ for $\mathrm{Hg}$ (Tab. S3).

The limit of detection (LOD) was calculated for every element (Tab. S3). We applied recovery corrections to the concentration measurements to estimate the effects of different microwave batches on the temporal trends of the concentrations (details presented in Tab. S5). The average recoveries per element ranged between 66 and $118 \%$ (U, Mn; Lake Fondococha) and 49 and $87 \%$ (Al, Fe; Lake Llaviucu) of the CRM 2709a values (we refer to their Table 3). A comparison of recovery corrected with not-recovery corrected concentration data revealed that their relative (temporal) trends are similar, and therefore, we decided to base further calculations on the not-recovery corrected concentration values. The reproducibility of the method was tested by replicate digests and analysis of selected samples (3 triplicates, 2 duplicates). The relative standard deviations (RSD) of the replicates ranged in average from $7 \%(\mathrm{~Pb})$ to $16 \%(\mathrm{Cr}$; Tab. $\mathrm{S} 4)$.

\section{Apportionment of elemental fluxes}

In principle, lake sediments integrate matter fluxes (e.g., trace elements) from different sources. To further interpret the causes of trace element accumulation, it is necessary to disentangle the contribution of the different sources to the total fluxes per element. It is particularly important to correct for the impact of lithogenic inputs (e.g., soil erosion; Hermanns and Biester 2013) on the total flux per element. One procedure is to normalize the concentrations of elements of interest with the concentrations of inert trace elements (e.g., Al, Zr, Ti; Hermanns and Biester 2013). However, due to low recoveries of $\mathrm{Al}, \mathrm{Zr}$, and $\mathrm{Ti}$ (elements typically used for such purposes), we followed a different approach. Perry et al. (2005) proposed to apportion the total flux of $\mathrm{Hg}\left(F_{\text {tot }}\right)$ to the lake sediments into (i) a fraction that reflects pre-anthropogenic "background" levels $\left(F_{\mathrm{B}}\right)$; (ii) a fraction $\left(F_{\mathrm{V}}\right)$ that is attributable to variations in soil erosion and lithogenic influx and, thus, mainly controlled by MAR; and (iii) a fraction $\left(F_{\mathrm{A}}\right)$ which is attributable to direct atmospheric fallout and non-lithogenic point sources (Perry et al. 2005). $F_{\mathrm{B}}$ and $F_{\mathrm{V}}$ are lake-specific and depend mostly on bedrock geology, "natural" erosion, and erosion due to anthropogenic activities in the watersheds. Perry et al. (2005) pointed out that MAR and, in consequence, $F_{\text {tot }}, F_{\mathrm{B}}, F_{\mathrm{V}}$, and $F_{\mathrm{A}}$ are highly dependent on the ${ }^{210} \mathrm{~Pb}$-chronology. A correction for sediment focusing as applied in Perry et al. (2005) was not possible as there is no regional standard ${ }^{210} \mathrm{~Pb}$ profile (sedimentary inventory) available in the CNP. Here, we applied this apportionment procedure to the other trace elements too. We calculated elemental fluxes $(F)$ at depth $i$ as $F_{i}=C_{i} \times \mathrm{MAR}_{i}$, where $C_{i}$ is the concentration of the trace element and MAR the mass accumulation rate. Following Perry et al. (2005), we defined "background" trace element flux $\left(F_{\mathrm{B}}\right)$ as the average pre1900 flux (to exclude bias, we compared pre-1900 also to pre-1800 and pre-1850, all three produced similar values), and $F_{\mathrm{V} i}$ as the fluxes at sediment depth $i$ attributable to variable MAR (assuming constant sediment composition; $F_{\mathrm{V} i}=$ $\left.\left\{\left(\mathrm{MAR}_{i} / \mathrm{MAR}_{\text {pre-1900 }} \times F_{\mathrm{B}}\right)-F_{\mathrm{B}}\right\}\right) . F_{\text {tot }}$ is defined as the total flux at sediment depth $i . F_{\mathrm{A} i}$ is defined as the flux attributable to atmospheric or non-lithogenic point sources to the lake at sediment depth $i\left(F_{\mathrm{A} i}=F_{\text {tot }}-F_{\mathrm{V} i}-F_{\mathrm{B}}\right)$.

\section{Results}

\section{General characteristics of sediments}

The visible characteristics of the background sediments (excluding the instantaneously deposited layers) from both lakes are very homogeneous throughout the investigated sediment core sections. They consist of brownish-black (HUE 10YR 2/1) organic diatomaceous fine silt with slightly darker and lighter bands (Figs. 2a and 3a). The lighter bands represent sediment sections with enhanced influx of lithogenic components. Scanning $\mu$ XRF analysis (K, Ca, Ti; Figs. 2a and 3a) underline the relatively stable sedimentary composition and indicate the lithogenic layers (more details provided in Bandowe et al. 2018).

The mass accumulation rate (MAR; Figs. $2 \mathrm{a}$ and $3 \mathrm{a}$ ) reconstructed from Lake Fondococha's sediment core is up to five times lower than the one measured in the sediments of Lake Llaviucu. However, the general trends (except within the layers of rapid sedimentation) compare well and both profiles do reveal a rapid MAR increase starting at ca. 1950, a significant MAR decrease between 1985 and ca. 1992 and thereafter again a slight MAR increase towards 2014. In both lakes, $\mathrm{C} / \mathrm{N}$ ratios are above 12 indicating both terrestrial and lacustrine origin of the organic material (Meyers 1994). In contrast to Lake Fondococha, where the $\mathrm{C} / \mathrm{N}$ ratio increases towards more recent times, the $\mathrm{C} / \mathrm{N}$ values in Lake Llaviucu show an 
Fig. 2 Chronology and trace element stratigraphy of Lake Fondococha. a Core image of Lake Fondococha with the ${ }^{210} \mathrm{~Pb}$ age-depth model (dashed line represents the extrapolated agedepth model, based on the lowest four samples), $\mathrm{C}$ fluxes, $\mathrm{C} / \mathrm{N}$ ratios and selected $\mu \mathrm{XRF}$-elements plotted along core-depth and $\mathbf{b}$ concentrations (dashed line) and fluxes (shaded) of discussed trace elements. The dotted horizontal line represents the start of the period based on the extrapolated age-depth model. Panel a was modified from Bandowe et al. (2018)

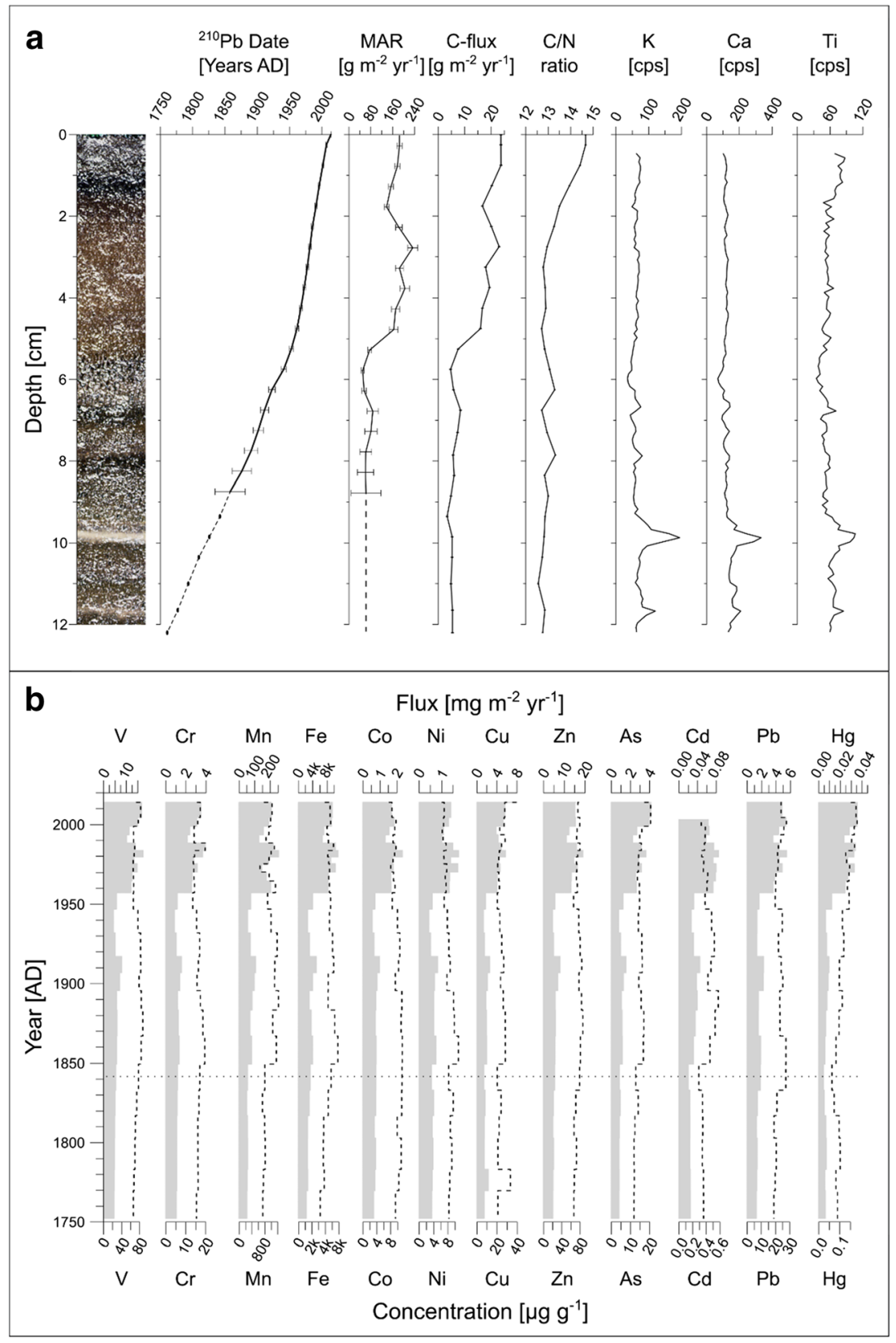

overall decreasing trend since 1950 (more details provided in Bandowe et al. 2018).

\section{Trace element concentrations and fluxes}

\section{Trace element trends in Lake Fondococha since 1760 AD}

The trace element concentrations in high-elevation and remote Lake Fondococha show remarkably constant values with only minor fluctuations between ca. 1760 and 2014 (Fig. 2b) and no (V, Cr, Co, Ni, Zn, Cd) or only slightly positive trends $(\mathrm{Cu}$, $\mathrm{As}, \mathrm{Pb})$ from ca. 1760 to 2014. The ratio of the average concentration in post-1950 sediments to the average concentration in pre-1950 sediments ranged from 0.8 to 1.1 (Table 1, Fig. 2b). Manganese and $\mathrm{Fe}$ concentrations are at least one order of magnitude higher compared to the other elements and show no increasing trend over the investigated sequence $(\mathrm{Mn}$ : 0.97; Fe: 1.01; post-1950/pre-1950). Mercury shows a 1.6fold post-1950 increase in concentrations compared to pre1950 average values.

The trace element concentrations are mostly below low effect levels (LEL, Persaud et al. 1993), i.e., typical threshold values from sediment quality guidelines (Table 1, MacDonald et al. 2000), except for $\mathrm{Cu}$, and As, where the pre- and post- 
Fig. 3 Chronology and trace element stratigraphy of Lake Llaviucu. a Core photograph of Lake Llaviucu with the ${ }^{210} \mathrm{~Pb}$ agedepth model (dashed line represents the extrapolated depth-age model, based on the lowest four samples), C fluxes, $\mathrm{C} / \mathrm{N}$ ratios, and selected $\mu \mathrm{XRF}$-elements plotted along core-depth and $\mathbf{b}$ concentrations (dashed line) and fluxes (shaded) of discussed trace elements. The dotted horizontal line represents the start of the period based on the extrapolated age-depth model. The red shadings in panel $\mathbf{b}$ highlight for the calculations excluded outliers (caused by high MAR due to rapid instantaneous event layers, flood layers). Panel a was modified from Bandowe et al. (2018)

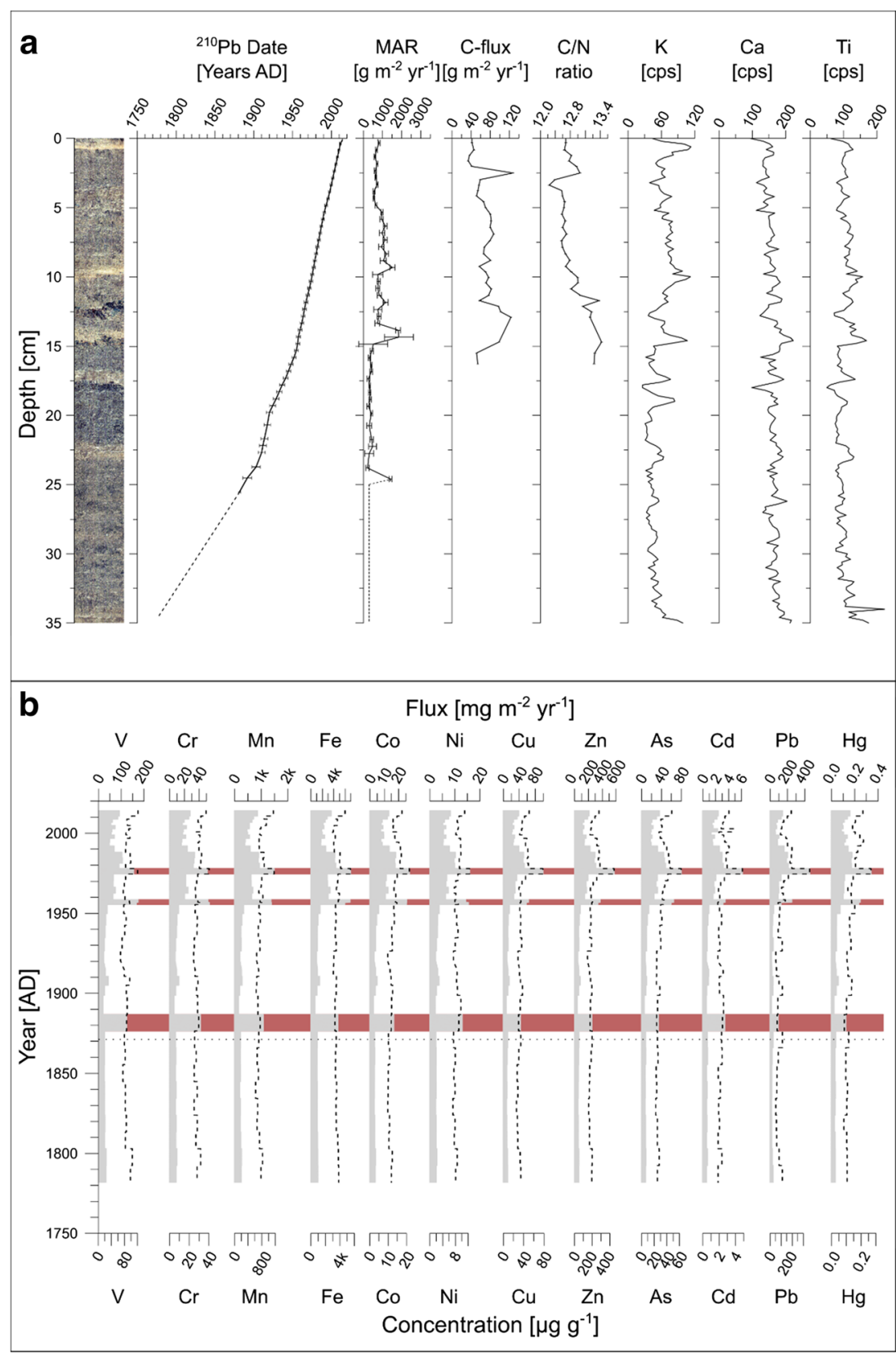

1950, and the most recent sediment concentrations ( $\mathrm{Cu}: 24.7-$ $33.4 \mu \mathrm{g} \mathrm{g}_{\mathrm{ds}}^{-1}$, As: $14.2-18.93 \mu \mathrm{g} \mathrm{g}_{\mathrm{ds}}^{-1}$ ) are 1.5-3 times higher than threshold values (Table 1).

The vertical concentration trends of As and $\mathrm{Hg}$ are positively correlated $(p<0.05)$ with the concentrations of total carbon and nitrogen $(\mathrm{C}, \mathrm{N}$; Pearson correlation matrix and PCA, Fig. S1), while Co (with C, N), Ni (with C, N), and $\mathrm{Sr}$ (with $\mathrm{C}$ ) are significantly negatively correlated. The correlations between all other trace element concentrations and $\mathrm{C}$ and $\mathrm{N}$ concentrations were not significant.

All trace element fluxes, including $\mathrm{Hg}$, remained nearly constant during the whole pre-1950 period (except for a synchronous temporary peak at around 1910) but increased rapidly from 1950 to 2014 . The post- 1950 fluxes were higher than the pre-1950 levels (ca. 1760-1950) by factors of $2.1(\mathrm{Ni})$ to 4.4 (Hg, Table 1). Between 1950 and 1970 an initial increase to higher modern values took place. Most trace elements showed maximum fluxes between 1970 and 1985 and increased again after a local minimum at around 1990. The fluxes of all investigated elements stayed at relatively high levels over the recent two decades.

\section{Trace element trends in Lake Llaviucu since 1760 AD}

In contrast to the small and remote high-altitude Lake Fondococha, trace element concentrations show larger 
Table 1 Lake Fondococha: TE (trace element), concentrations ( $\mu \mathrm{g}$ $\mathrm{g}_{\mathrm{ds}}^{-1}$ ) and fluxes (mg m${ }^{-2}$ year $^{-1}$ ) (pre-1950 and post-1950, not recovery corrected values, for recovery corrected values refer to Tab. S8), Factor (average in post-1950 sediments relative to the average in pre-1950 sediments), Recent (2 top samples, mean year: AD 2007), comparison with threshold effect concentrations (LEL-low effect level,
Persaud et al. 1993; ERL - effect range-low, Long and Morgan 1991) from sediment quality guidelines (SQG) in MacDonald et al. (2000), and comparison with threshold values in agricultural soils (TAS) after Toth et al. (2016) for trace elements in Lake Fondococha (bold: concentrations exceed LEL values of SQG; italics: concentrations exceed ERL values of SQG)

\begin{tabular}{|c|c|c|c|c|c|c|c|c|c|c|c|}
\hline \multirow[t]{2}{*}{$\mathrm{TE}$} & \multicolumn{4}{|c|}{$\begin{array}{l}\text { This study } \\
\text { Concentration }\left(\mu \mathrm{g} \mathrm{g}_{\mathrm{ds}}^{-1}\right)\end{array}$} & \multicolumn{2}{|c|}{ SQGs-LEL $\left(\mu \mathrm{g} \mathrm{g}^{-1}{ }_{\mathrm{ds}}\right)$} & \multirow[t]{2}{*}{ TAS $\left(\mu \mathrm{g} \mathrm{g}_{\mathrm{ds}}^{-1}\right)$} & \multicolumn{4}{|c|}{$\begin{array}{l}\text { This study } \\
\text { Flux }\left(\mathrm{mg} \mathrm{m}^{-2} \text { year }^{-1}\right)\end{array}$} \\
\hline & Pre-1950* & $1950-2014$ & Factor & Recent & LEL & ERL & & Pre-1950* & 1950-2014 & Factor & Recent \\
\hline $\mathrm{Cr}$ & 16.7 & 15.1 & 0.9 & 16.53 & 26 & 80 & 100 & 1.15 & 2.83 & 2.45 & 3.32 \\
\hline $\mathrm{Ni}$ & 8.82 & 6.97 & 0.79 & 6.65 & 16 & 30 & 200 & 0.61 & 1.3 & 2.14 & 1.34 \\
\hline $\mathrm{Cu}$ & 24.67 & 24.79 & 1 & 33.4 & 16 & 70 & 100 & 1.71 & 4.64 & 2.72 & 6.71 \\
\hline $\mathrm{Zn}$ & 76.29 & 74.05 & 0.97 & 75.97 & 120 & 120 & 200 & 5.29 & 13.87 & 2.62 & 15.27 \\
\hline As & 14.16 & 15.83 & 1.12 & 18.93 & 6 & 33 & 5 & 0.98 & 2.95 & 3.01 & 3.8 \\
\hline $\mathrm{Cd}$ & 0.42 & 0.37 & 0.87 & 0.29 & 0.6 & 5 & 1 & 0.03 & 0.07 & 2.3 & 0.06 \\
\hline $\mathrm{Pb}$ & 22.73 & 22.68 & 1 & 23.9 & 31 & 35 & 60 & 1.58 & 4.23 & 2.69 & 4.8 \\
\hline $\mathrm{Hg}$ & 0.094 & 0.153 & 1.63 & 0.17 & 0.2 & 0.15 & 0.5 & 0.006 & 0.028 & 4.39 & 0.03 \\
\hline $\mathrm{C}^{* *}$ & 79.95 & 102.44 & 1.3 & 117.89 & NA & & NA & 6.07 & 19.04 & 3.1 & 23.7 \\
\hline
\end{tabular}

*Includes data points pre $1850 ; * *$ multiplied by 1000

variability in the lower-altitude peri-urban Lake Llaviucu (Fig. 3b). They are relatively stable prior to 1950 , increase thereafter showing peak values in the mid-1970s, decrease to a relative local minimum at around 2000, and increase again towards recent times. The average concentrations in post-1950 sediments relative to the average concentrations in pre-1950 sediments (ratios) range from $1.0(\mathrm{Fe})$ to $1.9(\mathrm{~Pb}$; Fig. 3b,
Table 2). These factors are higher than those seen in Lake Fondococha (0.8-1.1; Table 1). The concentrations of $\mathrm{Cr}$, $\mathrm{Cu}, \mathrm{Zn}, \mathrm{As}, \mathrm{Cd}$, and $\mathrm{Pb}$ are the highest in these sediments and their values exceed the threshold values as specified in sediment quality guideline's LEL (Persaud et al. 1993) by factors of $1.2(\mathrm{Cr})$ to $6(\mathrm{As})$ and in the most recent sediments by factors of $1.3(\mathrm{Cr})$ to 7 (As; Table 2).
Table 2 Lake Llaviucu: TE (trace element), concentrations ( $\mu \mathrm{g} \mathrm{g}^{-1}$ ds and fluxes (mg m${ }^{-2}$ year $^{-1}$ ) (pre-1950 and post-1950, not recovery corrected values, for recovery corrected values refer to Tab. S9), Factor (average in post-1950 sediments relative to the average in pre-1950 sediments), Recent (2 top samples, mean year: AD 2011), comparison with threshold effect concentrations (LEL-low effect level, Persaud et al.
1993; ERL: effect range-low, Long and Morgan 1991) from sediment quality guidelines (SQG) in MacDonald et al. (2000), and comparison with threshold values in agricultural soils (TAS) after Toth et al. (2016) for trace elements in Lake Llaviucu (bold: concentrations exceed LEL values of SQG; italics: concentrations exceed ERL values of SQG)

\begin{tabular}{|c|c|c|c|c|c|c|c|c|c|c|c|}
\hline \multirow[t]{2}{*}{$\mathrm{TE}$} & \multicolumn{4}{|c|}{$\begin{array}{l}\text { This study } \\
\text { Concentration }\left(\mu \mathrm{g} \mathrm{g}_{\mathrm{ds}}^{-1}\right)\end{array}$} & \multicolumn{2}{|c|}{ SQGs-LEL $\left(\mu \mathrm{g} \mathrm{g}_{\mathrm{ds}}^{-1}\right)$} & \multirow[t]{2}{*}{$\operatorname{TAS}\left(\mu \mathrm{g} \mathrm{g}_{\mathrm{ds}}^{-1}\right)$} & \multicolumn{4}{|c|}{$\begin{array}{l}\text { This study } \\
\text { Flux }\left(\mathrm{mg} \mathrm{m}^{-2} \text { year }^{-1}\right)\end{array}$} \\
\hline & Pre-1950* & $1950-2014$ & Factor & Recent & LEL & ERL & & Pre-1950* & $1950-2014$ & Factor & Recen \\
\hline $\mathrm{Cr}$ & 27.1 & 29.8 & 1.1 & 34.41 & 26 & 80 & 100 & 8.68 & 22.57 & 2.6 & 26.92 \\
\hline $\mathrm{Ni}$ & 8.1 & 8.93 & 1.1 & 10.02 & 16 & 30 & 200 & 2.59 & 6.75 & 2.61 & 7.83 \\
\hline $\mathrm{Cu}$ & 31.73 & 40.67 & 1.28 & 46.35 & 16 & 70 & 100 & 10.17 & 31.09 & 3.06 & 36.23 \\
\hline $\mathrm{Zn}$ & 178.8 & 226.41 & 1.27 & 253.68 & 120 & 120 & 200 & 57.25 & 174.01 & 3.04 & 198.35 \\
\hline As & 25.87 & 35.84 & 1.39 & 42.23 & 6 & 33 & 5 & 8.29 & 27.67 & 3.34 & 32.96 \\
\hline $\mathrm{Cd}$ & 2.11 & 2.61 & 1.24 & 2.94 & 0.6 & 5 & 1 & 0.67 & 1.98 & 2.93 & 2.3 \\
\hline $\mathrm{Pb}$ & 76.82 & 141.94 & 1.85 & 173.37 & 31 & 35 & 60 & 24.63 & 110.55 & 4.49 & 135.46 \\
\hline $\mathrm{Hg}$ & 0.111 & 0.163 & 1.47 & 0.19 & 0.2 & 0.15 & 0.5 & 0.036 & 0.122 & 3.39 & 0.15 \\
\hline $\mathrm{C}^{* *}$ & 101.69 & 87.45 & 0.9 & 95.22 & NA & & NA & 53.84 & 70.8 & 1.3 & 43.63 \\
\hline
\end{tabular}

*Includes data points pre 1850; **includes values from 1940-2014 and was multiplied by 1000 
Except V, Mn, and Fe, the trace elemental concentrations show strong positive Pearson correlations among each other (Fig. S2).

In Lake Llaviucu, the average fluxes in post-1950 sediments relative to the average fluxes in pre-1950 sediments (post-1950 vs. pre-1950, Table 2) range mostly from a factor of $2.5(\mathrm{Fe})$ to $4.5(\mathrm{~Pb})$, i.e., slightly higher than those observed in Lake Fondococha (2.1 to 4.4; Table 1, Fig. 2b). However, the total fluxes (post-1950) are much higher in Lake Llaviucu compared to the fluxes calculated for Lake Fondococha (factor of 3.2-29.5, $\mathrm{Fe}<\mathrm{Cd}$; Table 3). Trace element fluxes determined in the topmost part of Lake Llaviucu's and Lake Fondococha's sediments are similar to trace element fluxes determined from the annually integrating sediment traps (2014-2015, Tab. S10), except for Fe and Mn, where the sediment traps recorded much higher values.

\section{Apportionment of trace elements into different sources}

\section{Changes in the sources of trace elements and $\mathrm{Hg}$ measured in the sediments of Lake Fondococha since $1760 \mathrm{AD}$}

The apportionment of the $\mathrm{Hg}$ and other trace element fluxes ( $F_{\text {tot }}, F_{\mathrm{B}}, F_{\mathrm{V}}$, and $\left.F_{\mathrm{A}}\right)$ measured in remote Lake Fondococha between ca. 1760 and 2014 is shown in Fig. 4a and Tab. S6. Remarkably, and for all investigated elements, the pre-1850, the pre-1900, and the pre-1950 total fluxes $\left(F_{\text {tot }}\right)$ are constant, indicating that $F_{\mathrm{B}}$ (defined here as pre-1900 $F_{\text {tot }}$ values) is a robust estimate of ambient background conditions. Between ca. 1760 and 1950 , contributions attributable to variable soil erosion and lithogenic flux $\left(F_{\mathrm{V}}\right)$ are low for $\mathrm{Cr}, \mathrm{Co}, \mathrm{Ni}, \mathrm{Cu}$,

Table 3 Comparison of total concentrations and fluxes between the two lakes (LLA — Lake Llaviucu; FON_Lake Fondococha) for pre-1950 and post-1950 values. Values are sorted after post-1950 fluxes

\begin{tabular}{llllll}
\hline Trace element & \multicolumn{2}{l}{ Concentrations: LLA/FON } & & \multicolumn{2}{l}{ Fluxes: LLA/FON } \\
\cline { 2 - 3 } \cline { 5 - 6 } \cline { 5 - 6 } & Pre-1950 & Post-1950 & & Pre-1950 & Post-1950 \\
\hline $\mathrm{Fe}$ & 0.77 & 0.79 & & 3.55 & 3.24 \\
$\mathrm{Mn}$ & 0.73 & 0.88 & & 3.38 & 3.59 \\
$\mathrm{Hg}$ & 1.18 & 1.06 & & 5.54 & 4.27 \\
$\mathrm{Ni}$ & 0.92 & 1.28 & & 4.25 & 5.19 \\
$\mathrm{~V}$ & 1.10 & 1.30 & & 5.08 & 5.26 \\
$\mathrm{Cu}$ & 1.29 & 1.64 & & 5.95 & 6.70 \\
$\mathrm{Co}$ & 1.07 & 1.67 & & 4.96 & 6.84 \\
$\mathrm{Cr}$ & 1.62 & 1.97 & & 7.53 & 7.98 \\
$\mathrm{As}$ & 1.83 & 2.26 & & 8.44 & 9.37 \\
$\mathrm{Zn}$ & 2.34 & 3.06 & & 10.83 & 12.54 \\
$\mathrm{~Pb}$ & 3.38 & 6.26 & & 15.63 & 26.11 \\
$\mathrm{Cd}$ & 4.99 & 7.13 & 23.09 & 29.49 \\
\hline
\end{tabular}

$\mathrm{Zn}, \mathrm{As}$, and $\mathrm{Pb}(\sim 3.5 \%$, Fig. 4a, Tab. S6) except for a small positive peak at around 1910. Also, their atmospheric and point source contributions $\left(F_{\mathrm{A}}\right)$ remain insignificant until 1950. For $\mathrm{Cd}$ and $\mathrm{Hg}$, both $F_{\mathrm{V}}$ and $F_{\mathrm{A}}(3.1 \%$, resp. 5.2$5.9 \%$; Fig. $4 \mathrm{a}, \mathrm{Tab} . \mathrm{S} 6$ ) show very low values, but in contrast to the other trace elements, $F_{\mathrm{A}}$ is higher than $F_{\mathrm{V}}$.

From 1950 to 2014, rapid increases of $F_{\text {tot }}$ are observed for $\mathrm{Cr}, \mathrm{Co}, \mathrm{Ni}, \mathrm{Cu}, \mathrm{Zn}, \mathrm{As}, \mathrm{Cd}, \mathrm{Hg}$, and $\mathrm{Pb}$. More than $85 \%$ of the post-1950 $F_{\text {tot }}$ of the trace elements is attributable to enhanced soil erosion $\left(F_{\mathrm{V}}\right)$ and background fluxes $\left(F_{\mathrm{B}}\right.$, Tab. S6). In the case of $\mathrm{Hg}, F_{\mathrm{V}}$ and $F_{\mathrm{B}}$ contribute $\sim 58 \%$ to the post- $1950 F_{\text {tot }}$ (Tab. S6). Between ca. 1970 and 1990, lithogenic contributions $\left(F_{\mathrm{V}}\right)$ exceed background fluxes $\left(F_{\mathrm{B}}\right)$ by a factor of approximately 2 and are the dominant source of all studied elements in Lake Fondococha's sediments.

Atmospheric contributions $\left(F_{\mathrm{A}}\right)$ in the past two decades (from 1996 to 2014) show negative values for $\mathrm{Cr}, \mathrm{Co}, \mathrm{Ni}$, $\mathrm{Zn}$, and Cd. Copper (15.7\%), As (26.2\%), and $\mathrm{Pb}(12.2 \%)$ show significantly higher $F_{\mathrm{A}}$ contributions. $F_{\mathrm{A}}$ of $\mathrm{Cu}$ shows additionally a rapid increase over the last decade, in contrast to the other trace elements measured in Lake Fondococha. For $\mathrm{Hg}, F_{\mathrm{A}}$ contributes with $42.2 \%$ at slightly higher importance as $F_{\mathrm{V}}(37.03 \%)$ to the post-1950 deposition. In the period from 1970 to $1990, F_{\mathrm{A}}(39.1 \%)$ is equally important as $F_{\mathrm{V}}$ (41.1\%). In the last two decades (from 1996 to 2014), the $F_{\mathrm{A}}$ of $\mathrm{Hg}(48.2 \%)$ becomes higher than the $F_{\mathrm{V}}(33.6 \%$, Tab. S6). Moreover, the increasing trend of $F_{\mathrm{A}}$ starts much earlier than for $\mathrm{Cu}, \mathrm{As}$, and $\mathrm{Pb}$.

\section{Relative contributions of different sources to the trace element and $\mathrm{Hg}$ content in Lake Llaviucu's sediments since $1780 \mathrm{AD}$}

The relative importance of the pre-1950 trace element sources measured in peri-urban lake Llaviucu (Fig. 4b) compares well with those determined in Lake Fondococha. Comparably low pre-1850, pre-1900, and pre-1950 fluxes in Lake Llaviucu suggest that $F_{\mathrm{B}}$ (from here on average pre-1900 fluxes) is representative and reflects background conditions. Therefore, $F_{\mathrm{B}}$ contributes with values up to $100 \%$ the most to the $F_{\text {tot }}$ of $\mathrm{Cr}, \mathrm{Co}, \mathrm{Ni}, \mathrm{Cu}, \mathrm{Zn}, \mathrm{As}, \mathrm{Cd}$, and $\mathrm{Pb}$ between ca. 1760 and 1950 (Tab. S7). Anthropogenic point sources and atmospheric input $\left(F_{\mathrm{A}}\right)$ contribute only between 2 and $4.5 \%$ to $F_{\text {tot }}$ of $\mathrm{Co}, \mathrm{Cu}, \mathrm{As}$, and $\mathrm{Pb}$. The lithogenic fractions $\left(F_{\mathrm{V}}\right)$ are negligible (Tab. S7). $F_{\mathrm{A}}$ of $\mathrm{Hg}$ is slightly higher and contributes approximately $8.9 \%$ to $F_{\text {tot }}$ (Tab. S7). Pre- $1950 F_{\mathrm{A}}$ (point sources and atmospheric contribution) of $\mathrm{Hg}$ calculated for Lake Llaviucu is slightly higher than in Lake Fondococha (5.9\%; Tab. S6). Interestingly, the temporary $F_{\text {tot }}$-peak (driven by an increase in $F_{\mathrm{V}}$ ) at around 1910 occurs also in the profiles of Lake Llaviucu and is synchronic to that observed in Lake Fondococha. 


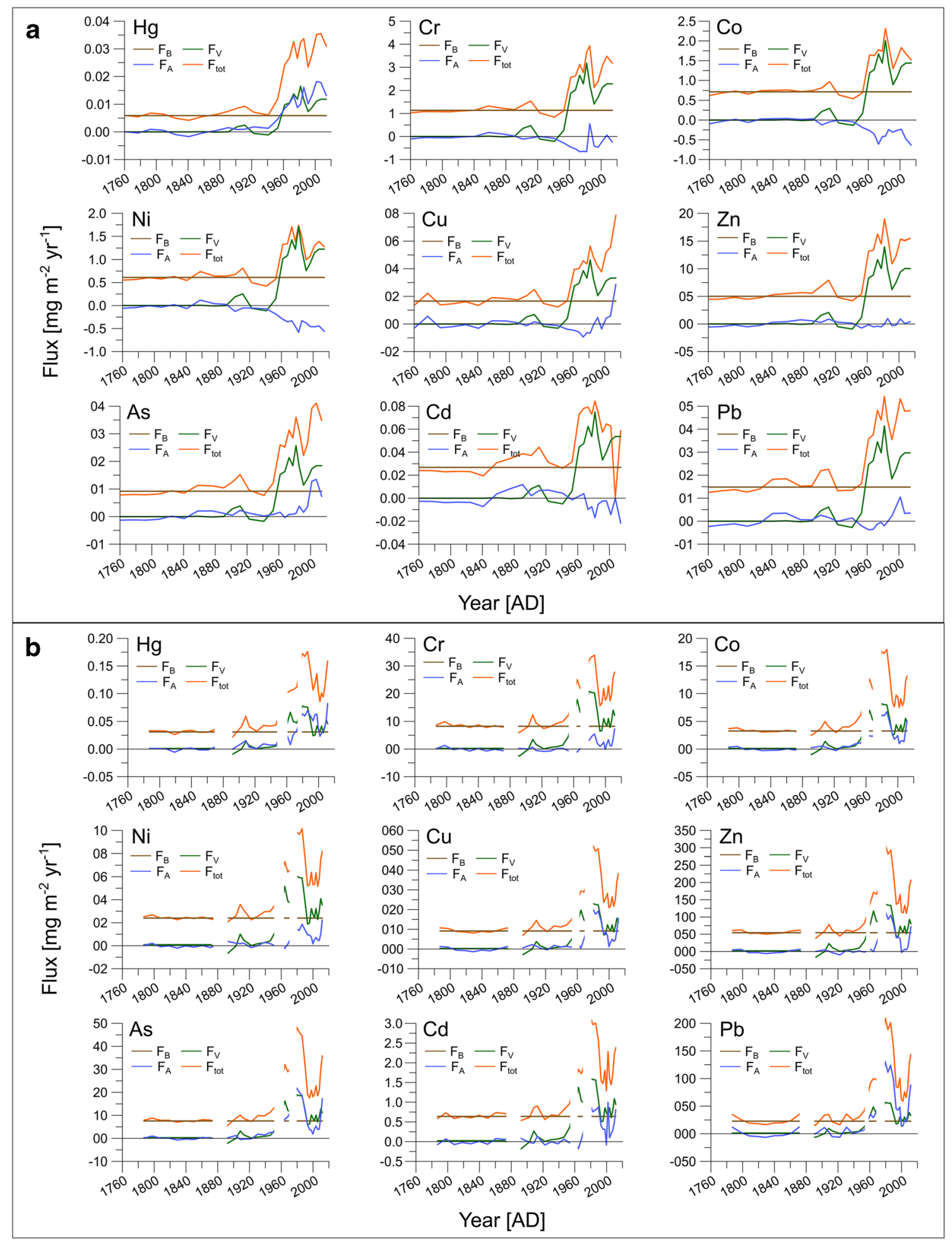

Fig. 4 Apportionment of total trace element fluxes. Background (pre$1900)$ fluxes $\left(F_{\mathrm{B}}\right)$, erosion-related fluxes $\left(F_{\mathrm{V}}\right)$, airborne fluxes $\left(F_{\mathrm{A}}\right)$, and total fluxes $\left(F_{\text {tot }}\right)$ for different trace elements measured in a Lake Fondococha ca. 1760-2014 and b Lake Llaviucu ca. 1785-2014.

The general picture of the post-1950 trace element sources in Lake Llaviucu, on the other hand, differs from remote Lake Fondococha (Fig. 4b): the non-lithogenic fraction $\left(F_{\mathrm{A}}\right)$ of
Please note that white gaps refer to the outliers presented in Fig. $3 \mathrm{~b}$. These samples were excluded from the calculations. Apportionments of further trace elements are presented in Fig. S3

most of the trace elements is substantially larger than in Lake Fondococha and shows positive values for all trace elements. $F_{\mathrm{A}}$ accounts for $7.5-8.8 \%(\mathrm{~V}<\mathrm{Cr}<\mathrm{Ni})$, or $16.3-$ 
$28.8 \%(\mathrm{Cd}<\mathrm{Zn}<\mathrm{Co}<\mathrm{Cu})$, or 35.8-53.8\% $(\mathrm{As}<\mathrm{Hg}<\mathrm{Pb})$ of $F_{\text {tot }}$ (total fluxes; Tab. S7). Lithogenic sources $\left(F_{\mathrm{V}}\right)$ contribute from 24.7 to $49.5 \%$ to the total fluxes ( $F_{\text {tot }}$, Tab. S7). The high $F_{\mathrm{A}}$ levels of $\mathrm{As}, \mathrm{Hg}$, and $\mathrm{Pb}$ peaked in the late $1960 \mathrm{~s}$ and between 1980 and $1990\left(F_{\mathrm{A}}>47.7 \%\right.$ of $F_{\text {tot }}$; Tab. S7). The drastic increase in $F_{\mathrm{A}}$ of $\mathrm{Cu}$ as observed in Lake Fondococha is not detected in Lake Llaviucu. However, in contrast to the pattern observed in Lake Fondococha, $F_{\text {tot }}$ values measured in Lake Llaviucu do show an increasing trend after the year 2000. This trend is mostly coinciding with an increase in $F_{\mathrm{A}}$ for all the trace elements presented in Fig. 4.

\section{Discussion}

We investigated the differences in $\mathrm{Hg}$ and other trace element depositions in two Ecuadorian Andean lakes, remote Lake Fondococha (4130 m a.s.l.) and peri-urban Lake Llaviucu (3140 $\mathrm{m}$ a.s.1.). It appears from Figs. 2 and 3 that variations in mass accumulation rates (MAR) are an important driver for the patterns and changes observed in the total fluxes. The element fluxes measured in Lake Llaviucu's and Lake Fondococha's sediment traps (Tab. S10), however, are comparable with those calculated for the most recent sediments. This suggests that the fluxes estimated for the down-core sediments are plausible.

The correlation coefficients among the most solid trace elements (Lake Fondococha: Fig. S1; Lake Llaviucu: Fig. S2) indicate a common source and common transport process of trace elements to the sediments. Only $\mathrm{Hg}$ and As show significant $(p<0.05)$ positive correlations (Hg: $r>0.84$; As: $r>0.56)$ with the concentrations of elements typical for organic matter (C, N, and S, Fig. S1), suggesting that their sources, cycling, and fate are partly linked to those of sedimentary organic matter.

Given South America's long history of trace element pollution (in particular Hg; Cooke and Abbott 2008; Cooke and Bindler 2015; Engstrom et al. 2014), it is likely that pre-1900 (similar to the pre-1800 and pre-1850) background levels $\left(F_{\mathrm{B}}\right)$ also contain an anthropogenic contribution. Our profiles, however, are too short to detect the undisturbed, natural background values. This in fact might affect the presented apportionment of fluxes $\left(F_{\mathrm{B}}, F_{\mathrm{V}}\right.$, and $\left.F_{\mathrm{A}}\right)$.

\section{Trace elements in Lakes Fondococha and Llaviucu}

\section{Pre-1950 trace element fluxes in the sediments of Lakes Fondococha and Llaviucu}

The pre-1950 trace element fluxes in both lakes were very constant except for the synchronic temporary peaks observed at around 1910. An obvious interpretation of such synchronous peaks in trace element fluxes might be the large scale deposition of volcanic tephra layers of nearby volcanoes (Konieczka et al. 2018; Arcusa et al. 2020). The results of tephrostratigraphic analyses reported by Arcusa et al. (2020), however, did not reveal any evidence of macro, nor crypto tephra layers in the two sediment sequences during this time. The apportionment of the total flux $\left(F_{\text {tot }}\right)$ peaks, on the other hand, revealed that in both lakes $F_{\mathrm{V}}$ (lithogenic, erosion) dominated. Bandowe et al. (2018) reported elevated concentrations and fluxes of low molecular weight (LMW) polycyclic aromatic compounds (PACs) in this lake during the same period (shown for Lake Fondococha in Fig. S4). LMW-PACs are indicative of biomass burning (Bandowe et al. 2018). Therefore, we suggest that these fires induced disturbance of the Páramo vegetation (Lake Fondococha), and shrubs and grassland (Lake Llaviucu) which, in turn, increased the erosion of the soils rich in volcanic material in their watersheds $\left(F_{\mathrm{V}}\right)$. Consequently, in the period of 1760 to 1950 , the two lake systems were mainly affected by variations caused directly in their watersheds (changes in $F_{\mathrm{V}}$ ).

\section{Post-1950 trace element and Hg fluxes in Lake Fondococha's sediments}

The apportionment of trace element and $\mathrm{Hg}$ fluxes $\left(F_{\mathrm{B}}, F_{\mathrm{V}}\right.$, $F_{\mathrm{A}}$, and $\left.F_{\text {tot }}\right)$ in remote high-altitude Lake Fondococha revealed that the post-1950 fluxes (until ca. 1995) are dominated by variations in $F_{\mathrm{V}}$ (except for $\mathrm{Hg}$, where $F_{\mathrm{A}}>F_{\mathrm{V}}$ ). The $F_{\mathrm{V}}$ patterns for the trace elements (except $\mathrm{Hg}$ ) in Lake Fondococha follow again similar trends as observed in the LMW PAC-reconstruction from Bandowe et al. (2018; Fig. S4). This might indicate that local anthropogenic activity (e.g., slash and burn techniques that lead to increased erosion) was still at a high level and may have dominated over other sources $\left(F_{\mathrm{A}}\right)$ of trace elements. The short-term relative drop by $20 \%$ in $F_{\text {tot }}$ (mostly caused by a drop in $F_{\mathrm{V}}$ ) can be attributed to restrictions in land use coming along with the establishment of the recreational area in 1977. In the cases of $\mathrm{Cu}, \mathrm{As}$, and $\mathrm{Pb}$, the relative short-term $F_{\mathrm{V}}$ decrease during the 1980-1990s is compensated by a strong relative increase of $F_{\mathrm{A}}$. We consider the opening of the Cuenca-Molleturo-Naranjal highway in 1991 with a traffic of currently more than 900,000 vehicles per year (data of 2012 from ETAPA EP) as a possible source for excess $\mathrm{Cu}$ and $\mathrm{Pb}$ (Hewitt and Candy 1990; Das et al. 2015). This increasing trend measured in Lake Fondococha's sediments occurred synchronous to a rising in high molecular weight PACs (HMW; formed during hightemperature combustion of fossil fuels, e.g., vehicles and industries) and underlines the impact of this highway on the lake systems (Fig. S4; Bandowe et al. 2018). Additionally, $F_{\mathrm{A}}$ (point sources, and airborne) of $\mathrm{Cu}$ shows a rapid increase in the last decade, which could be further promoted by newly established mining areas around the park (Roy et al. 2018). 
The situation is very different for $\mathrm{Hg}$, where $\sim 42.2 \%$ of the post-1950 deposition can be attributed to $F_{\mathrm{A}}$ (here presumably mostly atmospheric deposition; Tab. S6). Given the potentially long traveling time of $\mathrm{Hg}$ in the atmosphere (Schroeder and Munthe 1998; Phillips et al. 2011), sources from long-distance transport are plausible (Beal et al. 2014) and are possibly more important than local point sources. The sources of some PACs measured in Lake Fondococha (Bandowe et al. 2018 in Fig. S4) was similarly attributed to this mechanism (dominance of long-distance transported sources).

\section{Post-1950 trace element and $\mathrm{Hg}$ fluxes in Lake Llaviucu's sediments}

The composition of the post-1950 trace element and $\mathrm{Hg}$ sources are more variable in peri-urban Lake Llaviucu compared to Lake Fondococha. Particularly, the high contribution of $F_{\mathrm{A}}\left(F_{\mathrm{A}}\right.$ regularly $>40 \%$ of $F_{\text {tot }} ;$ Fig. $4 \mathrm{~b}$, Tab. S7) to $F_{\text {tot }}$ of $\mathrm{Co}, \mathrm{Ni}, \mathrm{Cu}, \mathrm{Zn}, \mathrm{Cd}$, and $\mathrm{Pb}$ between 1970 and 1990 is different from that observed in Lake Fondococha. We consider traffic (combustion, dust from tire-rubber and brakes-friction) and industrial dust from the metropolitan area of Cuenca as possible airborne sources (Hewitt and Candy 1990; Das et al. 2015). Intensive caged fishery (aquaculture, fish fodder $(\mathrm{Cu})$, fertilizer, Xia et al. 2018; and antifouling $(\mathrm{Cu})$ treatment of nets, Loucks et al. 2012) between 1978 and 1998 in Lake Llaviucu (data provided by ETAPA EP) might be an additional local point source of trace elements responsible for the observed excess fluxes $\left(F_{\mathrm{A}}\right)$ during this period. For example, a systematic survey of different lakes in the central Yangtze River basin revealed a close positive relationship between aquaculture stocking size and measured trace element concentrations (Xia et al. 2018). Furthermore, we suggest that the different geography of Lake Llaviucu (e.g., microclimatology- located below cloud layer, large catchment-to-lake ratio- $\sim 14$ times higher than Lake Fondococha, and differences in vegetation cover) leads to higher (than Lake Fondococha) $F_{\text {tot }}$ of the particle-bound elements $(\mathrm{Cr}, \mathrm{Co}, \mathrm{Ni}, \mathrm{Cu}, \mathrm{Zn}, \mathrm{Cd}$, and $\mathrm{Pb})$ and also shapes the relative contributions of the different sources to the $F_{\text {tot }}$. For example, the particle-bound trace elements can be scavenged in the cloud layer, wet-deposited, and lead to higher concentrations in Lake Llaviucu (and hence, would not reach Lake Fondococha). Mercury (mostly in gaseous phase; Phillips et al. 2011) on the other hand, shows a similar source composition as observed in Lake Fondococha $\left(F_{\mathrm{A}}: 40.5 \%\right.$, Tab. S7) within the same period. This indicates that $\mathrm{Hg}$ is not efficiently scavenged by the cloud layer. However, the observed increase in $F_{\mathrm{A}}$ of $\mathrm{Hg}$ in Lake Llaviucu is also synchronic with the $F_{\mathrm{A}}$ of the other trace elements. This also could suggest that the amount of $\mathrm{Hg}$ deposited in Lake Llaviucu is more driven by the nearby urban activities than by long-distance transport.
The comparison of the absolute post- $1950 F_{\mathrm{A}}$ fluxes of $\mathrm{Hg}$, $\mathrm{As}, \mathrm{Cu}$, and $\mathrm{Pb}$ (all positive in both lakes) as presented in Fig. 5 reveals that differences in the geography (e.g., watershed size, cloud layer position, vegetation cover, vicinity to urban center) may affect the distribution of particle-bound trace elements more than the distribution of the mostly gaseous Hg. However, it is important to keep in mind that the local point sources (caged fishery) present in Lake Llaviucu's watershed may bias this comparison.

\section{Limitation of the implemented approach}

We attribute negative $F_{\mathrm{A}}$ values $\left(F_{\mathrm{A}}=F_{\text {tot }}-F_{\mathrm{B}}-F_{\mathrm{V}}\right)$, as observed for some of the trace elements in Lake Fondococha (post-1950; e.g., Cr, Co, Ni, Cd), to an artifact of the calculations after Perry et al. (2005). The total fluxes $\left(F_{\text {tot }}\right)$ are fixed and hence, do not directly influence $F_{\mathrm{A}}$. Therefore, negative $F_{\mathrm{A}}$ values result from the overestimation of either $F_{\mathrm{B}}$ or $F_{\mathrm{V}}$. Background fluxes $\left(F_{\mathrm{B}}\right)$ can be overestimated due to (i) high MAR pre-1900 or (ii) high elemental concentrations pre1900. However, the shapes of $F_{\text {tot }}$ in Fig. 4 reveal that post$1950 F_{\text {tot }}$ values are generally higher than pre-1900 values (here the same as $F_{\mathrm{B}}$ ) and hence, $F_{\mathrm{B}}$ alone cannot explain negative values. Therefore, it is likely that $F_{\mathrm{V}}$ can be overestimated too. Perry et al. (2005) used a regional ${ }^{210} \mathrm{~Pb}$ inventory encompassing ${ }^{210} \mathrm{~Pb}$-profiles of different regional lakes and inferred a regional standard MAR to account for sedimentary focusing effects. Due to a lack of ${ }^{210} \mathrm{~Pb}$-profiles in our study region, however, it was not possible to implement this in a similar way. Yet, this would not explain, why the approach worked for all elements in the case of Lake Llaviucu (no negative values) and for the other elements in Lake Fondococha. Therefore, we suggest that it must be a feature specific to $\mathrm{Cr}, \mathrm{Co}, \mathrm{Ni}$, and $\mathrm{Cd}$ in Lake Fondococha's watershed. One reason here could be that the watershed's soil composition in the post-1950 period is depleted in $\mathrm{Cr}, \mathrm{Co}, \mathrm{Ni}$, and $\mathrm{Cd}$ and that therefore, $F_{\mathrm{B}}$ of these trace elements would be overestimated. Furthermore, the cumulative uncertainties (RSD: 11-16\%; and variations in recovery rates post-1950 to pre-1950) of these specific elements could have resulted in the negative $F_{\mathrm{A}}$ values too. Keeping these caveats in mind, we therefore suggest that in the interpretation of the different source fractions presented in this study, emphasis should be placed on the tendencies and trends rather than on the absolute values.

\section{Regional, global comparison and implications}

\section{Trace element profiles}

Peak fluxes of $\mathrm{Co}, \mathrm{Ni}, \mathrm{Cu}, \mathrm{Zn}$, As, and $\mathrm{Cd}$ measured in the sediments of Lake Fondococha are similar to those observed in Lake Chipian, a high-altitude (4350 $\mathrm{m}$ a.s.l) lake in the 
Fig. 5 Sketch depicting the source to sink pathways of trace elements in Cajas National Park. Lake Llaviucu is the lowerelevation lake, located in the vicinity of the city of Cuenca and Lake Fondococha is situated at a relatively remote distance from Cuenca. The table represents average post-1950 fluxes of $F_{\mathrm{A}}$ (point sources and airborne fraction) and $F_{\mathrm{V}}$ (soil erosion). This figure was modified from Bandowe et al. (2018)

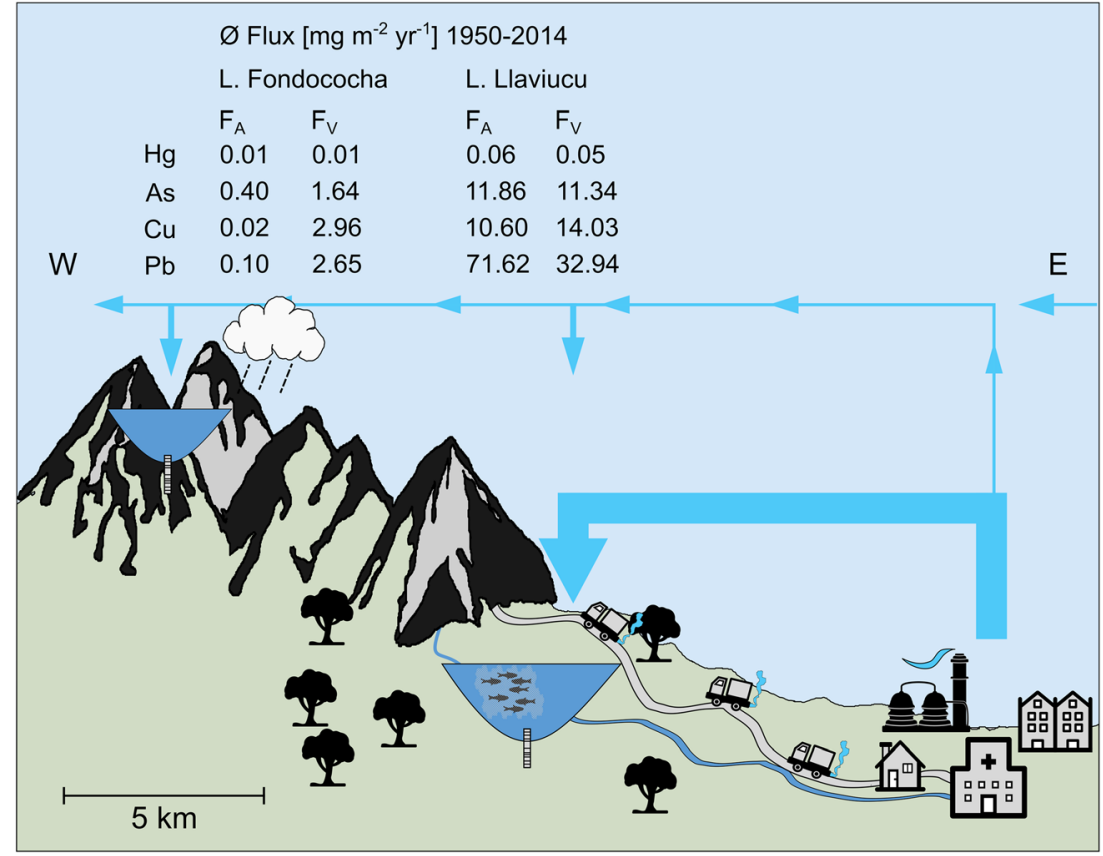

vicinity $(\sim 15 \mathrm{~km})$ of Cerro de Pasco, a Peruvian city, which is famous for its mining activities (Cooke and Abbott 2008). However, trace element fluxes in Lake Chipian show the initial modern increases (around 1935-1940), and peak values (mid-1950s) earlier than Lake Fondococha (in the 1970s). In contrast to Lake Fondococha, Lake Chipian recorded decreasing fluxes of $\mathrm{Cu}, \mathrm{Zn}, \mathrm{As}, \mathrm{Cd}$, and $\mathrm{Pb}$ since the 1960s. The relative flux patterns observed in Lake Fondococha (except for $\mathrm{Co}, \mathrm{Ni}$, and $\mathrm{As}$ ) is comparable with those reconstructed from Lake Pirhuacocha, a small high-altitude lake $(4520 \mathrm{~m}$ a.s.l), which is nearby $(11 \mathrm{~km})$ a modern silver mine in the Peruvian Morococha mining region (Cooke and Abbott 2008). This lake recorded a similar strong onset in the 1950 s and peak values at around 1975. A decrease towards 2000 (topmost sample in their study) is also comparable to Lake Fondococha's trace element profile. Absolute flux values, however, were higher (2-33-fold) in the Peruvian lake. The temporal variations of Lake Llaviucu's trace element profiles are mostly similar to those recorded in Lake Pirhuacocha (Cooke and Abbott 2008), but peak values are generally higher in Lake Llaviucu (up to a 5-fold).

Lake Fondococha's trace elemental concentrations compare well with those from remote Lake Bolterskardet (Svalbard, Sun et al. 2006). Furthermore, post-1950 peak fluxes lay in the same order of magnitude $(0.4-10$-fold $\mathrm{Pb}<$ $\mathrm{Cu})$ as those reconstructed from two remote high-altitude lakes in the center of the Adirondack mountains region (NY, USA, Sarkar et al. 2015). Here, differences can mostly be explained with differences in the bedrock composition, since $F_{\mathrm{V}}$ was the dominant source. Lake Llaviucu's post-1950 peak values, however, are $13(\mathrm{~Pb})$ to $81(\mathrm{Cu})$ times higher, representing the peri-urban influences.
Skordas et al. (2015) provide a compilation (we refer to their Table 2) of surface sedimentary heavy metal concentrations from different lakes in the northern hemisphere. Surface sediment concentrations of $\mathrm{Cr}, \mathrm{Ni}$, and $\mathrm{Pb}$ determined in Lake Fondococha are in the lower third, $\mathrm{Cu}$ in the medium range, and $\mathrm{Co}$ and $\mathrm{Zn}$ lay at the upper end (peak values in Lake Fondococha were slightly higher). Interestingly, maximum $\mathrm{Zn}$ and $\mathrm{Pb}$ concentrations in Lake Llaviucu's sediments are a 1.2- to 1.5-fold higher than the highest reported in Skordas et al. (2015). The other elemental concentrations (except Ni) compare with the medium and high concentrations recorded in Skordas et al. (2015). We suggest that, besides differences in bedrock composition (volcanic material), mostly the point sources (caged fishery) and the proximity of Lake Llaviucu to urban activities caused such high concentrations.

\section{Mercury profiles}

The profiles of $\mathrm{Hg}$ fluxes from the two studied lakes (from ca. 1760 to 2014) show some differences to profiles reported from the northern hemisphere (mostly a delayed modern-era onset; Perry et al. 2005; Engstrom et al. 2014; Sarkar et al. 2015; Yang et al. 2016; Engels et al. 2018). The delayed onset of steep increases of $\mathrm{Hg}$ fluxes in recent times, however, was also observed in other sites from South America (Peru: Beal et al. 2013; Chile: Álvarez et al. 2018, Guédron et al. 2019; Hermanns and Biester 2013).

Noteworthy are the nearly constant pre- $1950 \mathrm{Hg}$ fluxes of $6.5 \mathrm{\mu g} \mathrm{m}^{-2}$ year $^{-1}$ (Lake Fondococha) and $35.9 \mu \mathrm{g} \mathrm{m}^{-2}$ year $^{-1}$ (Lake Llaviucu) to both lakes. This contrasts with most other records worldwide where a marked and steady increase in the $\mathrm{Hg}$ fluxes was recorded during this time. Even reconstructions 
from western Canadian Alpine lakes (Phillips et al. 2011) and Arctic lake systems (Outridge et al. 2007) recorded a continuous increase in $\mathrm{Hg}$ fluxes over this period.

Lake Fondococha's record does not reflect the structure of historical global or regional $\mathrm{Hg}$ emissions (Streets et al. 2011). Apparently, Lake Fondococha is far enough away from areas with substantial local primary or secondary $\mathrm{Hg}$ anthropogenic emissions, such as cinnabar mining or historical $\mathrm{Hg}$ emissions related to amalgamation in silver or gold mines, located in southern Ecuador (Tarras-Wahlberg et al. 2000; Betancourt et al. 2005), Peru or Bolivia (Cooke and Abbott 2008; Cooke et al. 2009; Cooke and Bindler 2015). Similar observations were reported from three high-altitude lakes from Peru (PLS5, PLS8, and PLS12; Beal et al. 2013).

The record from Lake Fondococha reflects rather background levels of a well-mixed atmosphere in the tropics and long-distance transport in the pre-1950 period $\left(\sim 6.5 \mu \mathrm{g} \mathrm{m}^{-2}\right.$ year $^{-1} \mathrm{Hg}$; Table 3 ) and values of anthropogenic point and airborne sources $\left(F_{\mathrm{A}}\right) \mathrm{Hg}$ during the post-1950 increase (12 $\mu \mathrm{g} \mathrm{m}^{-2}$ year $^{-1}$ ) that are very similar to values found in other remote lake systems: high-elevation lakes in Rocky Mountains (Mast et al. 2010), Lake Challa (Tanzania), Lake El Junco (Galapagos), or Lake Tahoe (Sierra Nevada; Engstrom et al. 2014). The enhanced long-distance transported PAC-input measured in Lake Fondococha (compared to the one measured in Lake Llaviucu; Bandowe et al. 2018) further supports the finding that $\mathrm{Hg}$ in this lake has significant contributions from long-range transport sources.

The post-1950 period of Lake Fondococha resembles the profiles of Peruvian lakes (Beal et al. 2013), Lake Chungará (northern high-altitude Chilean Andes; Guédron et al. 2019), and rural Lake Pillo (south-central Chile, low-altitude; Álvarez et al. 2018). For example, Lake Fondococha's peak $\mathrm{Hg}$ flux values observed in the post-1950 period (from 24 to $33 \mu \mathrm{g} \mathrm{m}^{-2}$ year $^{-1}$ ) correspond very well to those seen in Lake Chungará during the industrial era. The relative pattern of rural Lake Pillo is similar too, but absolute values are up to ten times higher. Peri-urban Lake Llaviucu's post-1950 Hg flux pattern on the other hand shows similarities to the one observed in urban Lake Señoraza (south-central Chile; Álvarez et al. 2018) with a temporary peak at around 1980 and a decrease thereafter. Absolute peak fluxes (from 160 up to $177 \mathrm{\mu g} \mathrm{m}^{-2}$ year $^{-1}$ ) are comparable to those measured in Lake Señoraza, a lake which is highly influenced by urban activities.

The wind field in Cajas National Park with predominantly NE/E flow from the northern Amazon basin (Schneider et al. 2018) and the tropical Atlantic supports the view that transport of contaminated air from the hotspots of $\mathrm{Hg}$ emissions in Peru and Bolivia is very limited. This can also explain the differences observed in the $\mathrm{Hg}$ profile measured in Bolivian Altiplano (Guédron et al. 2018). It is also debatable to what extent historical atmospheric $\mathrm{Hg}$ loads from the northern hemisphere midlatitudes (Perry et al. 2005) were mixed and transported to our study site in southern Ecuador. Interestingly, the uniquely low ${ }^{137} \mathrm{Cs}$ fallout rates that were found in several lakes across Ecuador (Gunkel 2003; Bandowe et al. 2018) suggest that transport of air from the mid-latitudes of both hemispheres to the southern Andes of Ecuador is very limited. This would provide evidence for the existence of a chemical equator (a distinct atmospheric division between the northern hemisphere and the southern hemisphere) in this part of Ecuador (Hamilton et al. 2008).

Finally, the $\mathrm{Hg}$ record of Lake Fondococha, in particular $F_{\mathrm{A}}$ of $\mathrm{Hg}$ deposition, supports the view of Engstrom et al. (2014) that historical (here starting ca. 1760) atmospheric $\mathrm{Hg}$ loads were potentially smaller than previously thought (e.g., Streets et al. 2011). The increase of atmospheric $\left(F_{\mathrm{A}}\right)$ $\mathrm{Hg}$ deposition between pre-1950 and the post- 1950 periods by a factor of $4.4\left(\mathrm{Hg}_{\text {tot }} ; \mathrm{Hg}_{\mathrm{A}}=31.6\right)$ in Lake Fondococha and $3.4\left(\mathrm{Hg}_{\text {tot }} ; \mathrm{Hg}_{\mathrm{A}}=14.2\right)$ in Lake Llaviucu, respectively, is at the upper end of the range that has been observed elsewhere (Pirrone et al. 2010; Engstrom et al. 2014).

Our results confirm previous findings from Peru (Cooke and Abbott 2008) that showed that the long-distance atmospheric contribution of rather particulate trace elements in the high Ecuadorian Andes are negligible (except for weak contributions of volatile $\mathrm{Hg}$ ). This stands in contrast to findings from other high-altitude lake systems as for example observed in the Eastern Tibetan Plateau (Bing et al. 2016).

\section{Conclusions}

We present sedimentary trace element and $\mathrm{Hg}$ fluxes reconstructed from two Andean lakes in the Cajas National Park (Lake Fondococha: $4130 \mathrm{~m}$ a.s.1., and Lake Llaviucu: $3140 \mathrm{~m}$ a.s.1.). The two sedimentary reconstructions (approximately 250 years long) represent the first trace element records from this region.

The reconstructions from both lakes showed relatively stable pre-1950 trace element fluxes and concentrations. They compare well with each other, as well as with other profiles from South America. But they differ from other study sites reported on the northern hemisphere. The apportionment of the source contributions to the pre-1950 trace element fluxes revealed that pre-1950 fluxes mostly depended on changes directly caused in the watershed (e.g., loss of vegetation and increased erosion due to fires and land use). This agrees with the findings of the recently published polycyclic aromatic compound (PACs) reconstructions from Lake Fondococha (Bandowe et al. 2018).

Both lakes registered a strong increase in trace element fluxes between the late 1950s and 1960s. Differences in the post-1950 deposition patterns of lower-elevation and peri- 
urban Lake Llaviucu indicate that airborne fraction and local point sources started to become more important for $\mathrm{Hg}, \mathrm{Cu}$, $\mathrm{As}$, and $\mathrm{Pb}$. In remote high-altitude Lake Fondococha, post1950 fluxes are mainly driven by changes in the catchment, except for $\mathrm{As}, \mathrm{Hg}, \mathrm{Pb}$, and most recently also $\mathrm{Cu}$.

Interestingly, the post-1950 fraction $F_{\mathrm{A}}$ (point-sources and atmospheric contribution) of $\mathrm{Hg}$ is similar in both lakes (Lake Fondococha: 42.5\%; Lake Llaviucu: 40.5\%). The $\mathrm{Hg}$ deposition pattern in remote Lake Fondococha reveals that long-distance atmospheric transport was an important source. A similar importance of long-range transport was also observed for the recent PAC reconstructions from Lake Fondococha (Bandowe et al. 2018). The $F_{\mathrm{A}}$ of the particle-bound trace elements, on the other hand, is much lower in the high-elevation lake compared to lowerelevation Lake Llaviucu (Lake Fondococha: < 13.5\%; Lake Llaviucu: up to 54\%). We explain differences in the $F_{\text {A }}$ profiles with Lake Llaviucu's vicinity to urban activities (traffic, industrial emissions) as well as its exposure to direct sources (caged fishery).

Most element fluxes measured in Lake Fondococha do compare with other remote lake systems (Andes, Arctic). Lake Llaviucu, on the other hand, recorded flux and concentrations comparable with values measured in lake sediments on the northern hemisphere. Even though the park regulations (1977) showed positive effects on both lakes (temporary drop in fluxes), the highway through the park and recently established mining areas around the park affected and can further impact these lake systems and potentially lift the concentrations above threshold levels (ecosystem health).

Supplementary Information The online version contains supplementary material available at https://doi.org/10.1007/s11356-020-11437-0.

Acknowledgments ETAPA EP is acknowledged for granting research permission in the Cajas National Park, and providing traffic data and information about the caged fishery. We thank Mario Cordova for supporting us with meteorological and limnological data. We thank Dr. Daniela Fischer for her assistance in the laboratory. The participation of $\mathrm{HH}$ in this project and in the preparation of this manuscript took place in the context of the project "Análisis de la variación temporal de las características físico-químicas y biológicas de los lagos del Parque Nacional Cajas (PNC)."

Authors' contributions MG and TS designed the study. Sedimentological and geochemical lab work was performed by LF, GW, TS, and BAMB and supported by MB and AM. WT conducted the radionuclide dating. HV provided the XRF measurements. $\mathrm{HH}$ and PM provided the meteorological and limnological data and helped with logistics. TS did the numerical age-depth modeling, the statistical analysis, and the figures. TS, MG, and BAMB wrote the manuscript with inputs from all authors.

Funding Open access funding provided by University of Bern. This work was supported by the Swiss National Science Foundation grant 200021_ 152986.
Data availability The data and calculations presented in this manuscript can be found online at https://boris.unibe.ch/ (BORIS, University of Bern, Switzerland)

\section{Compliance with ethical standards}

Ethical approval Not applicable.

Consent to participate Not applicable.

Consent to publish Not applicable.

Competing interests The authors declare that they have no competing interests.Supplementary Information The online version contains supplementary material available at https://doi.org/10.1007/s11356-020$11437-0$

Open Access This article is licensed under a Creative Commons Attribution 4.0 International License, which permits use, sharing, adaptation, distribution and reproduction in any medium or format, as long as you give appropriate credit to the original author(s) and the source, provide a link to the Creative Commons licence, and indicate if changes were made. The images or other third party material in this article are included in the article's Creative Commons licence, unless indicated otherwise in a credit line to the material. If material is not included in the article's Creative Commons licence and your intended use is not permitted by statutory regulation or exceeds the permitted use, you will need to obtain permission directly from the copyright holder. To view a copy of this licence, visit http://creativecommons.org/licenses/by/4.0/.

\section{References}

Álvarez D, Torrejón F, Climent MJ, Garcia-Orellana J, Araneda A, Urrutia R (2018) Historical anthropogenic mercury in two lakes of Central Chile: comparison between an urban and rural lake. Environ Sci Pollut Res 25:4596-4606. https://doi.org/10.1007/s11356-0170622-x

Appleby PG, Oldfield F (1978) The calculation of lead-210 dates assuming a constant rate of supply of unsupported $210 \mathrm{~Pb}$ to the sediment. Catena 5:1-8

Arcusa SH, Schneider T, Mosquera PV, Vogel H, Kaufman D, Szidat S, Grosjean M (2020) Late Holocene tephrostratigraphy from Cajas National Park, southern Ecuador. Andean Geol. 47:508. https:// doi.org/10.5027/andgeoV47n3-3301

Bandowe BAM, Fränkl L, Grosjean M, Tylmann W, Mosquera PV, Hampel H, Schneider T (2018) A 150-year record of polycyclic aromatic compound (PAC) deposition from high Andean Cajas National Park, southern Ecuador. Sci Total Environ 621:16521663. https://doi.org/10.1016/j.scitotenv.2017.10.060

Beal SA, Jackson BP, Kelly MA, Stroup JS, Landis JD (2013) Effects of historical and modern mining on mercury deposition in southeastern Peru. Environ Sci Technol 47:12715-12720. https://doi.org/10. 1021/es402317x

Beal SA, Jackson BP, Kelly MA, Stroup JS, Landis JD (2014) Natural and anthropogenic variations in atmospheric mercury deposition during the Holocene near Quelccaya Ice Cap, Peru. Global Biogeochem Cycles 28:437-450. https://doi.org/10.1021/ es $402317 \mathrm{x}$ 
Betancourt O, Narváez A, Roulet M (2005) Small-scale gold mining in the Puyango River Basin, Southern Ecuador: a study of environmental impacts and human exposures. Ecohealth 2:323-332. https://doi. org/10.1007/s10393-005-8462-4

Biester H, Bindler R, Martinez-Cortizas A, Engstrom DR (2007) Modeling the past atmospheric deposition of mercury using natural archives. Environ Sci Technol 41:4851-4860. https://doi.org/10. 1021/es0704232

Bing H, Wu Y, Zhou J, Li R, Wang J (2016) Historical trends of anthropogenic metals in Eastern Tibetan Plateau as reconstructed from alpine lake sediments over the last century. Chemosphere 148: 211-219. https://doi.org/10.1016/j.chemosphere.2016.01.042

Boyle J, Chiverrell R, Schillereff D (2015) Lacustrine archives of metals from mining and other industrial activities-a geochemical approach. In: Blais JM, Rosen MR, Smol JP (eds) Environmental contaminants: using natural archives to track sources and long-term trends of pollution. Springer Netherlands, Dordrecht, pp 121-159

Chojnacka K (2018) Introduction. In: Recent advances in trace elements. John Wiley \& Sons, Ltd, pp 1-10

Colinvaux PA, Bush MB, Steinitz-Kannan M, Miller MC (1997) Glacial and postglacial pollen records from the Ecuadorian Andes and Amazon. Quat Res 48:69-78. https://doi.org/10.1006/qres.1997. 1908

Cooke CA, Abbott MB (2008) A paleolimnological perspective on industrial-era metal pollution in the central Andes, Peru. Sci Total Environ 393:262-272. https://doi.org/10.1016/j.scitotenv.2007.12. 034

Cooke CA, Bindler R (2015) Lake sediment records of preindustrial metal pollution. In: Blais JM, Rosen MR, Smol JP (eds) Environmental contaminants. Springer, Dordrecht, pp 101-119

Cooke CA, Balcom PH, Biester H, Wolfe AP (2009) Over three millennia of mercury pollution in the Peruvian Andes. Proc Natl Acad Sci 106: 8830-8834. https://doi.org/10.1073/pnas.0900517106

Croudace IW, Rindby A, Rothwell RG (2006) ITRAX: description and evaluation of a new multi-function X-ray core scanner. In: Rothwell RG (ed) New techniques in sediment core analysis, special Publication. Geological Society, London, pp 51-63

D'llio S, Majorani C, Petrucci F et al (2010) Method validation for the quantification of $\mathrm{As}, \mathrm{Cd}, \mathrm{Hg}$ and $\mathrm{Pb}$ in blood by ICP-MS for monitoring purposes. Anal Methods 2:2049-2054. https://doi.org/10. 1039/c0ay00429d

Das R, Khezri B, Srivastava B, Datta S, Sikdar PK, Webster RD, Wang X (2015) Trace element composition of PM2.5 and PM10 from Kolkata - a heavily polluted Indian metropolis. Atmos Pollut Res 6:742-750. https://doi.org/10.5094/APR.2015.083

Djedjibegovic J, Larssen T, Skrbo A, Marjanović A, Sober M (2012) Contents of cadmium, copper, mercury and lead in fish from the Neretva river (Bosnia and Herzegovina) determined by inductively coupled plasma mass spectrometry (ICP-MS). Food Chem 131: 469-476. https://doi.org/10.1016/j.foodchem.2011.09.009

Driscoll CT, Mason RP, Chan HM, Jacob DJ, Pirrone N (2013) Mercury as a global pollutant: sources, pathways, and effects. Environ Sci Technol 47:4967-4983. https://doi.org/10.1021/es305071v

Engels S, Fong LSRZ, Chen Q, Leng MJ, McGowan S, Idris M, Rose NL, Ruslan MS, Taylor D, Yang H (2018) Historical atmospheric pollution trends in Southeast Asia inferred from lake sediment records. Environ Pollut 235:907-917. https://doi.org/10.1016/j. envpol.2018.01.007

Engstrom DR, Fitzgerald WF, Cooke CA, Lamborg CH, Drevnick PE, Swain EB, Balogh SJ, Balcom PH (2014) Atmospheric Hg emissions from preindustrial gold and silver extraction in the Americas: a reevaluation from lake-sediment archives. Environ Sci Technol 48: 6533-6543. https://doi.org/10.1021/es405558e

Fitzgerald WF, Engstrom DR, Mason RP, Nater EA (1998) The case for atmospheric mercury contamination in remote areas. Environ Sci Technol 32:1-7. https://doi.org/10.1021/es970284w
Guédron S, Ledru MP, Escobar-Torrez K, Develle AL, Brisset E (2018) Enhanced mercury deposition by Amazonian orographic precipitation: evidence from high-elevation Holocene records of the Lake Titicaca region (Bolivia). Palaeogeogr Palaeoclimatol Palaeoecol 511:577-587. https://doi.org/10.1016/j.palaeo.2018.09.023

Guédron S, Tolu J, Brisset E, Sabatier P, Perrot V, Bouchet S, Develle AL, Bindler R, Cossa D, Fritz SC, Baker PA (2019) Late Holocene volcanic and anthropogenic mercury deposition in the western Central Andes (Lake Chungará Chile). Sci Total Environ 662: 903-914. https://doi.org/10.1016/j.scitotenv.2019.01.294

Gunkel G (2003) Limnología de un Lago Tropical de Alta Montaña, en Ecuador: Características de los sedimentos y tasa de sedimentación. Rev Biol Trop 51:381-390

Hamilton JF, Allen G, Watson NM, Lee JD, Saxton JE, Lewis AC, Vaughan G, Bower KN, Flynn MJ, Crosier J, Carver GD, Harris NRP, Parker RJ, Remedios JJ, Richards NAD (2008) Observations of an atmospheric chemical equator and its implications for the tropical warm pool region. J Geophys Res Atmos 113:1-12. https://doi.org/10.1029/2008JD009940

Hansen BCS, Rodbell DT, Seltzer GO, León B, Young KR, Abbott M (2003) Late-glacial and Holocene vegetational history from two sites in the western Cordillera of southwestern Ecuador. Palaeogeogr Palaeoclimatol Palaeoecol 194:79-108. https://doi. org/10.1016/S0031-0182(03)00272-4

Hermanns YM, Biester H (2013) Anthropogenic mercury signals in lake sediments from southernmost Patagonia, Chile. Sci Total Environ 445-446:126-135. https://doi.org/10.1016/j.scitotenv.2012.12.034

Hewitt CN, Candy GBB (1990) Soil and street dust heavy metal concentrations in and around Cuenca, Ecuador. Environ Pollut 63:129136. https://doi.org/10.1016/0269-7491(90)90063-I

Kassambara A, Mundt F (2017) factoextra: extract and visualize the results of multivariate data analyses, R package version 1.0.4. https:// CRAN.R-project.org/package=factoextra. Accessed 1 June 2017

Konieczka P, Cieślik B, Namieśnik J (2018) Trace elements in aquatic environments. In: Recent advances in trace elements. John Wiley \& Sons, Ltd, Hoboken, pp 143-160

Landers DH, Gubala C, Verta M, Lucotte M, Johansson K, Vlasova T, Lockhart WL (1998) Using lake sediment mercury flux ratios to evaluate the regional and continental dimensions of mercury deposition in arctic and boreal ecosystems. Atmos Environ 32:919-928

Li Y, Chen C, Li B, Sun J, Wang J, Gao Y, Zhao Y, Chai Z (2006) Elimination efficiency of different reagents for the memory effect of mercury using ICP-MS. J Anal At Spectrom 21:94-96. https:// doi.org/10.1039/b511367a

Long ER, Morgan LG (1991) The potential for biological effects of sediment-sorbed contaminants tested in the National Status and Trends Program. NOAA Technical Memorandum NOS OMA 52, National Oceanic and Atmospheric Administration, Seattle, WA, 175 pp 1 appendices. https://udspace.udel.edu/handle/19716/1562. Accessed 29 Sept 2020

Loucks RH, Smith RE, Fisher CV, Brian Fisher E (2012) Copper in the sediment and sea surface microlayer near a fallowed, open-net fish farm. Mar Pollut Bull 64:1970-1973. https://doi.org/10.1016/j. marpolbul.2012.05.025

MacDonald DD, Ingersoll CG, Berger TA (2000) Development and evaluation of consensus-based sediment quality guidelines for freshwater ecosystems. Arch Environ Contam Toxicol 39:20-31. https:// doi.org/10.1007/s002440010075

Mackey EA, Christopher SJ, Lindstrom RM et al (2010) Certification of three NIST renewal soil standard reference materials for element content: SRM 2709a San Joaquin Soil, SRM 2710a Montana Soil I, and SRM 2711a Montana Soil II. NIST Spec Publ 260:1-39

Mast MA, Manthorne DJ, Roth DA (2010) Historical deposition of mercury and selected trace elements to high-elevation National Parks in the Western U.S. inferred from lake-sediment cores. Atmos Environ 44:2577-2586. https://doi.org/10.1016/j.atmosenv.2010.04.024 
Meyers PA (1994) Preservation of elemental and isotopic source identification of sedimentary organic matter. Chem Geol 114:289-302

Mosquera PV, Hampel H, Vázquez RF, Alonso M, Catalan J (2017) Abundance and morphometry changes across the high-mountain lake-size gradient in the tropical Andes of Southern Ecuador. Water Resour Res 53:7269-7280. https://doi.org/10.1002/ 2017WR020902

Oksanen J, Guillaume BF, Kindt R et al (2019) vegan: community ecology package. R package version 2:5-6

Outridge PM, Sanei H, Stern GA et al (2007) Evidence for control of mercury accumulation rates in Canadian High Arctic Lake sediments by variations of aquatic primary productivity. Environ Sci Technol 41:5259-5265. https://doi.org/10.1021/es070408x

Paladines A, Guzmán J, Instituto Geográfico Militar (1980) Mapa geologico del Ecuador. Dirección General de Geología y Minas, Hoja 53 Geolõgica de Cuenca. Escala: 1:100,000. Quito

Perry E, Norton SA, Kamman NC, Lorey PM, Driscoll CT (2005) Deconstruction of historic mercury accumulation in lake sediments, northeastern United States. Ecotoxicology 14:85-99. https://doi.org/ 10.1007/s10646-004-6261-2

Persaud D, Jaagumagi R, Hayton A (1993) Guidelines for the protection and management of aquatic sediment quality in Ontario. Water Resources Branch, Ontario Ministry of the Environment, Toronto, 27 pp. https://www.itrcweb.org/contseds-bioavailability/ References/guide_aquatic_sed93.pdf. Accessed 29 Sept 2020

Phillips VJA, St. Louis VL, Cooke CA, Vinebrooke RD, Hobbs WO (2011) Increased mercury loadings to Western Canadian Alpine Lakes over the past 150 years. Environ Sci Technol 45:2042 2047. https://doi.org/10.1021/es1031135

Pirrone N, Hedgecock IM, Cinnirella S, Sprovieri F (2010) Overview of major processes and mechanisms affecting the mercury cycle on different spatial and temporal scales. EPJ Web Conf 9:3-33. https://doi.org/10.1051/epjconf/201009002

R Core Team (2019) R: a language and environment for statistical computing. R Foundation for Statistical Computing, Vienna, Austria. https://www.R-project.org/. Accessed 15 Jan 2019

Rauch JN, Pacyna JM (2009) Earth's global Ag, Al, Cr, Cu, Fe, Ni, Pb, and Zn cycles. Global Biogeochem Cycles 23:1-16. https://doi.org/ 10.1029/2008GB003376

Roy BA, Zorrilla M, Endara L, Thomas DC, Vandegrift R, Rubenstein JM, Policha T, Ríos-Touma B, Read M (2018) New mining concessions could severely decrease biodiversity and ecosystem services in Ecuador. Trop Conserv Sci 11:1-20. https://doi.org/10.1177/ 1940082918780427

Sarkar S, Ahmed T, Swami K, Judd CD, Bari A, Dutkiewicz VA, Husain L (2015) History of atmospheric deposition of trace elements in lake sediments, $\sim 1880$ to 2007 . J Geophys Res Atmos 120:5658-5669. https://doi.org/10.1002/2015JD023202

Schneider T, Hampel H, Mosquera PV, Tylmann W, Grosjean M (2018) Paleo-ENSO revisited: Ecuadorian Lake Pallcacocha does not reveal a conclusive El Niño signal. Glob Planet Change 168:54-66. https://doi.org/10.1016/j.gloplacha.2018.06.004

Schnurrenberger D, Russell J, Kelts K (2003) Classification of lacustrine sediments based on sedimentary components. J Paleolimnol 29: 141-154. https://doi.org/10.1023/A:1023270324800

Schroeder WH, Munthe J (1998) Atmospheric mercury - an overview. Atmos Environ 32:809-822. https://doi.org/10.1016/S13522310(97)00293-8

Selin NE, Jacob DJ, Yantosca RM, Strode S, Jaeglé L, Sunderland EM (2008) Global 3-D land-ocean-atmosphere model for mercury: present-day versus preindustrial cycles and anthropogenic enrichment factors for deposition. Global Biogeochem Cycles 22:1-13. https://doi.org/10.1029/2007GB003040
Skordas K, Kelepertzis E, Kosmidis D, Panagiotaki P, Vafidis D (2015) Assessment of nutrients and heavy metals in the surface sediments of the artificially lake water reservoir Karla, Thessaly, Greece. Environ Earth Sci 73:4483-4493. https://doi.org/10.1007/s12665014-3736-1

Smol JP (2008) Pollution of lake and rivers: a paleoenvironmental perspective, Second. Blackwell Publishing, Oxford

Steffen W, Broadgate W, Deutsch L, Gaffney O, Ludwig C (2015) The trajectory of the anthropocene: the great acceleration. Anthr Rev 2: 81-98. https://doi.org/10.1177/2053019614564785

Streets DG, Devane MK, Lu Z, Bond TC, Sunderland EM, Jacob DJ (2011) All-time releases of mercury to the atmosphere from human activities. Environ Sci Technol 45:10485-10491. https://doi.org/10. $1021 / \mathrm{es} 202765 \mathrm{~m}$

Strode S, Jaeglé L, Selin NE (2009) Impact of mercury emissions from historic gold and silver mining: global modeling. Atmos Environ 43: 2012-2017. https://doi.org/10.1016/j.atmosenv.2009.01.006

Sun Q, Chu G, Liu J, Gao D (2006) A 150-year record of heavy metals in the varved sediments of Lake Bolterskardet, Svalbard. Arctic, Antarct Alp Res 38:436-445. https://doi.org/10.1657/15230430(2006)38[436:AYROHM]2.0.CO;2

Sundseth K, Pacyna JM, Pacyna EG, Pirrone N, Thorne RJ (2017) Global sources and pathways of mercury in the context of human health. Int J Environ Res Public Health. 14, 105: 0-14. https://doi.org/10.3390/ ijerph14010105

Tarras-Wahlberg NH, Flachier A, Fredriksson G, Lane S, Lundberg B, Sangfors O (2000) Environmental Impact of Small-scale and Artisanal Gold Mining in Southern Ecuador. AMBIO A J Hum Environ 29:484-491. https://doi.org/10.1579/0044-7447-29.8.484

Tchounwou PB, Yedjou CG, Patlolla AK, Sutton DJ (2012) Heavy metal toxicity and the environment. In: Luch A (ed) Molecular, clinical and environmental toxicology, Environmental toxicology, vol 3. Springer Basel, Basel, pp 133-164

Tylmann W (2014) Reply to the comment by F. Gharbi on "Multiple dating of varved sediments from Lake q azduny, northern Poland: toward an improved chronology for the last 150 years". Quat Geochronol 20:111-113. https://doi.org/10.1016/j.quageo.2013.04. 003

Tylmann W, Bonk A, Goslar T, Wulf S, Grosjean M (2016) Calibrating ${ }^{210} \mathrm{~Pb}$ dating results with varve chronology and independent chronostratigraphic markers: problems and implications. Quat Geochronol 32:1-10. https://doi.org/10.1016/j.quageo.2015.11.004

von Gunten L, Grosjean M, Beer J, Grob P, Morales A, Urrutia R (2009) Age modeling of young non-varved lake sediments: methods and limits. Examples from two lakes in Central Chile. J Paleolimnol 42: 401-412. https://doi.org/10.1007/s10933-008-9284-5

Wei T, Simko V (2017) Corrplot: visualization of a correlation matrix, Rpackage version 0.84. https://github.com/taiyun/corrplot. Accessed 01 June 2017

Xia W, Qu X, Zhang Y, Wang R, Xin W, Guo C, Bowker J, Chen Y (2018) Effects of aquaculture on lakes in the Central Yangtze River Basin, China, III: heavy metals. N Am J Aquac 80:436-446. https:// doi.org/10.1002/naaq.10060

Yang J, Chen L, Steele JC, Chen RS, Meng XZ (2016) An extended study on historical mercury accumulation in lake sediment of Shanghai: the contribution of socioeconomic driver. Environ Pollut 219:612-619. https://doi.org/10.1016/j.envpol.2016.06.028

Publisher's note Springer Nature remains neutral with regard to jurisdictional claims in published maps and institutional affiliations. 